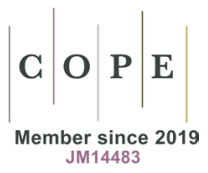

\title{
On Several Polish Poems From 1829-1870 with Venice in the Background
}

\section{S U M MARY}

The subject of the article is a review of images of Venice recorded in Polish poetry between the years 1829-1870. The paper deliberately stops in the 1870s in the selection of the literary material to be analysed, focusing on the Romantic and post-Romantic tradition. Due to the different artistic value of the works, the author adopted the formula of a historical and literary "catalogue" ordered chronologically and partly problematicised according to the functions which Venetian scenery or culture perform in them. Attention is drawn to the fact that Venetian motifs present in the poetry of Polish artists tend to be related to particular phenomena and topics, such as Byronism, Gothicism, political and national camouflage, love and existential masks, conflict between people and power. The authors referred to in the paper include, among others, Adam Mickiewicz, Józef Ignacy Kraszewski, Zygmunt Krasiński, Edward Dembowski, Edmund Chojecki, Karol Baliński, Mieczysław Gwalbert Pawlikowski, Teofil Lenartowicz, Feliks Wicherski, Teofil Nowosielski, Aleksander Michaux and Wiktor Gomulicki.

\section{Keywords}

Venice, Polish and Italian affinities, 19th century poetry, Bridge of Sighs, political camouflage 
Over the centuries, Polish-Venetian relations have been reflected in various literary forms. The Nobles' Republic was modelled on the structure of the Venetian government, seeing it as the foundation of civil order and a guarantee of security, in particular for the upper classes. Even some eighteenth-century accounts of journeys to Venice contain numerous expressions of admiration for La Serenissima's well-functioning system of power, worthy of imitation in the country's increasingly dysfunctional reality. ${ }^{1}$ Writing about "Wyjątek mojej podróży do Włoch" [An Excerpt to My Trip to Italy] by Henryk Rzewuski (1846), Iwona Węgrzyn referred to the name of Gasparo Contarini, whose work titled De magistratibus et Republica Venetorum was immensely popular among Old Polish political writers. ${ }^{2}$ In turn, "Wenecja" [Venice], a well-known poem by Krzysztof Warszewicki (1572), proved that an analysis of the political system of the Republic of Venice in the context of its wars with Turkey was a starting point for a programme of similar activities conducted in Poland. In the nineteenth century, Venice became a surprising centre of the first political emigration of Poles in the wake of the Kościuszko Uprising and the Third Partition. Grzegorz Kaczyński reminds us that "it was only at the turn of 1795 and 1796 that 150 Polish immigrants passed through Venice." ${ }^{3}$ Although, on the one hand, the Republic of Venice did not condemn the partitions, maintaining a far-reaching neutrality, and on the other, many Poles strengthened Bonaparte's army occupying the "pearl of the Adriatic," the mutual relations in the nineteenth century still remained, in principle, quite friendly, which does not mean that they were uncritical. According to researchers,

Polish immigrants (...) met with solidarity and support through an analogous political and social situation (similar sources and nature of social inequality as well as the same invader, Austria $\left.^{4}\right)$, due to convergent po-

${ }^{1}$ Cf. e.g.: Stanisław Kot, Venezia vista dai Polacchi nel corso dei secoli (Venezia: Montuoro, 1947); Diana Kozińska-Donderi, I viaggi dei Polacchi in Italia attraverso i secoli (Moncalieri: Cirvi, 2006); La porta d'Italia. Diari e viaggiatori polacchi in Friuli-Venezia Giulia dal XVI al. XIX secolo, eds. Lucia Burello, Andrzej Litwornia (Udine: Forum Edizioni, 2000).

${ }^{2}$ Iwona Węgrzyn, W świecie powieści Henryka Rzewuskiego (Krakow: Wydawnictwo Uniwersytetu Jagiellońskiego, 2012), 340-341. Cf. also: Bronisław Biliński, "Viaggiatori polacchi a Venezia nei secoli XVII-XIX," in Venezia e la Polonia nei secoli XVII-XIX, ed. Luigi Cini (Venice-Rome: Istituto per la collaborazione culturale, 1965), 341-417; Danuta Quirini-Popławska, Mit czy rzeczywistość późnośredniowiecznej Wenecji?: urbs populosissima, opulentissima, liberalissima (Krakow: Wydawnictwo Uniwersytetu Jagiellońskiego, 1997); Krzysztof Pomian, Wenecja w kulturze europejskiej (Lublin: Wydawnictwo Uniwersytet Marii Curie-Skłodowskiej, 2000); Mieczysław Brahmer, Powinowactwa polsko-włoskie (Warsaw: PWN, 1980). [Unless indicated otherwise, quotations in English were translated from Polish.]

${ }^{3}$ Grzegorz J. Kaczyński, “Geneza i obraz polskiej emigracji we Włoszech,” in Polacy we Włoszech. Historia, współczesność, zmiany, eds. Karolina Golemo, Bartosz Kaczorowski, Małgorzata Stefanowicz (Krakow: Ośrodek Myśli Politycznej, 2014), 41-69. Accessed November 28, 2020. www.academia.edu/14897219/Polacy_we_Włoszech_Historia_współczesność_zmiany_ Poles_in_Italy_History_Contemporaneity_Changes_; Cf. also: Jan Pachoński, “Emigracja polska w Wenecji w latach 1794-1797. Wenecja i jej znaczenie dla emigracji polskiej," Kwartalnik Historyczny, no. 4 (1968): 869-893.

4 The Austrians took over Venice from the French in the wake of the peace in Campo Formio on 17 October 1797, and it again briefly passed under Napoleon's rule eight years later (1805). After the defeat of Bonaparte in 1814, Austria ruled Venice until the formation of the 
litical goals (the struggle for independence and national unity) as well as historical and cultural closeness between the two countries. (...) The social bond, formed on the basis of revolutionary beliefs of independence, turned out to be stronger than local patriotism. ${ }^{5}$

Thus, it was due to tradition, history and politics as well as the Romantic, post-Byronic fashion that the Venetian theme would return in Polish literature, music, and art in various forms of artistic, journalistic and documentary or scientific expression. This article is aimed at analysing only poetic works, limited mainly to the inter-insurrectional period since it seems necessary to deal separately with the image of the city developed by Polish lyricism of the last three decades of the nineteenth century, influenced by strong Parnassian, symbolic or - more broadly - modernist movements. This applies, among others, to the "Venetian" poems by Maria Konopnicka, Wiktor Gomulicki, Antoni Lange, Kazimierz Przerwa-Tetmajer, Władysław Karoli, Kazimierz Gliński or Helena Rogozińska that are not mentioned here yet they are indeed extremely interesting. The reading of the earlier lyrics, in turn, arises out of an objection with regard to Olga Płaszczewska's rather minor remark made in an otherwise excellently and competently written monograph titled Wizja Włoch w polskiej i francuskiej literaturze okresu romantyzmu (1800-1850) [A Vision of Italy in Polish and French Literature of the Romantic Period (1800-1850)] in which she argues that "The poetic paths of the Polish Romantics actually bypassed Venice."6 I thought it was worthwhile to take a closer look at this phenomenon.

\section{Byron is the key}

Of course, it was George Byron that had the greatest influence on the poetic representation of Venice in the first decades of the 19th century. His legend in Poland was co-created by the Romantics through, among others, their translation attempts: Adam Mickiewicz rendered fragments of Childe Harold's Pilgrimage, The Giaour and poems such as Darkness or The Dream"; Antoni Edward Odyniec translated The Corsair, The Bride of Abydos and many

United Kingdom of Italy in 1866, with a short break for the uprising in 1848. Cf. e.g. John Julius Norwich, Historia Wenecji (Warsaw: W.A.B. 2015); Peter Ackroyd, Wenecja. Biografia (Poznań: Zysk i S-ka, 2015).

${ }^{5}$ Kaczyński, “Geneza i obraz polskiej emigracji we Włoszech,” 5.

${ }^{6}$ Olga Płaszczewska, Wizja Włoch w polskiej i francuskiej literaturze okresu romantyzmu (1800-1850) (Krakow: Universitas, 2003), 297.

${ }^{7}$ It was not only the generation of Romantics that was interested in Byron; the first translations were accomplished by Brunon Kiciński and Julian Ursyn Niemcewicz, but young poets were the closest to Byron's diction and poetic expression, and thus the power of impact, in terms of language and style. Hence, the choice of names proposed here. Zygmunt Dokurno wrote that "For Mickiewicz, the famous English Romantic was not only a great poet, but also an exponent of up-to-date progressive ideas: 'Only Byron do I read, I throw away a book written in a different spirit for I do not like lies' - as he confesses in his letter to Malewski." Cf. Zygmunt Dokurno, "O mickiewiczowskich przekładach z Byrona," Pamiętnik Literacki, no. 47 (1956): 317-348; also Wanda Krajewska, "Polskie przekłady powieści poetyckich Byrona w okresie romantyzmu," Pamiętnik Literacki, no. 71/1 (1980): 153-174. 
other poems; Ignacy Szydłowski and Wanda Małecka rendered Parisina; Julian Korsak translated Lara, A Tale; and Antoni Czajkowski - Beppo; not taking into account some minor translations, for instance, by Aleksander Chodźko, Stefan Garczyński or August Bielowski. As the goal this time is to expose Venetian themes taken from Byron or inspired by his writings, it is worth recalling that for the English artist Venice is a place of extreme contrasts which now, however, mostly belong to the dim and distant past.

I stood in Venice, on the Bridge of Sighs,

A palace and a prison on each hand:

I saw from out the wave her structures rise

As from the stroke of the enchanter's wand:

A thousand years their cloudy wings expand

Around me, and a dying Glory smiles

O'er the far times, when many a subject land

Looked to the wingéd Lion's marble piles,

Where Venice sate in state, throned on her hundred isles! ${ }^{8}$

The contemporary Venice of the poet creates less and squanders more of what she has gained over the centuries. The city still retains its grandeur, but it is keeps fading, leaning, aging. The elements of beauty, wealth and masquerade have faded, although a certain deceptive spell has been preserved, coming not so much from the tangible heritage as from the imagination of the artists who grew out of the magic of the "maritime empire."

In Venice Tasso's echoes are no more,

And silent rows the songless gondolier;

Her palaces are crumbling to the shore,

And music meets not always now the ear:

Those days are gone - but Beauty still is here.

States fall, arts fade - but Nature doth not die,

Nor yet forget how Venice once was dear,

The pleasant place of all festivity,

The revel of the earth, the masque of Italy!

But unto us she hath a spell beyond

Her name in story, and her long array

Of mighty shadows, whose dim forms despond

Above the dogeless city's vanish'd sway;

Ours is a trophy which will not decay

With the Rialto; Shylock and the Moor,

And Pierre, cannot be swept or worn away -

The keystones of the arch! though all were o'er,

For us repeopl'd were the solitary shore. ${ }^{9}$

\footnotetext{
${ }^{8}$ George Byron, Childe Harold's Pilgrimage, Canto IV, accessed October 8, 2020, https:// www.gutenberg.org/files/5131/5131-h/5131-h.htm\#link2H_4_0006.

${ }_{9}^{9}$ Byron, Childe Harold's Pilgrimage.
} 
However, the most important flaw in the Venice of his day is the enslavement that extends from the Ponte dei Sospiri prison to everything:

Her thirteen hundred years of freedom done,

Sinks, like a sea-weed, into whence she rose!

Better be whelm'd beneath the waves, and shun,

Even in destruction's depth, her foreign foes,

From whom submission wrings an infamous repose..$^{10}$

As a result, Byron sees "a desolate cloud o'er Venice' lovely walls."11

A somewhat more amusing, not to say - more frivolous - image of Venice was left by Byron in his poem titled Beppo, A Venetian Story, a comedy of manners written in 1818, in which a slightly provocative and slightly exotic story comes to the fore, dealing with "wonders," "of berets, scarves / the last days of the carnival in Italy and balls in Venice"12 - in any case, quite far from the moral principles publicly approved of in the Polish reality. Perhaps that is why the translator, Antoni Czajkowski, preceded the publication of the first excerpts from his translation of Beppo with a rhymed preface, where he explained that although the Lord's life was full of various scandals, the blame lies with unfavourable circumstances and his rather immoral and not very prudent companions of life. In the final verse, he encouraged his blue-eyed readers ("Polish girls") to perceive the author as a fugitive despised by his compatriots, who turned to the Greek and Italian worlds, drawing artistic inspiration from them. Referring to Byron's ambiguous fame in Venice, he suggested:

Tak na wygnaniu skończył dni żywota
Wy naszej ziemi szlachetne dziewczyny
Przebaczcie jemu jak Bóg wszystkie winy -
Wszak się litować stara ojców cnota,
Bo gdyby on był Lachem nie Anglikiem
Przy was by nigdy nie został grzesznikiem.
In that way he ended his days in exile
May you, the noble girls of our land,
Forgive him, like God, all his faults -
As it is our fathers' old virtue to take pity,
For if he were a Pole and not an Englishman
He'd never have become a sinner by your side.

Which of these Byronic perspectives inspired Polish poets to a greater extent?

Let us start with Mickiewicz's "Morlach w Wenecji. Z serbskiego" [Morlach in Venice. Translated from Serbian], referred to by Krystyna Poklewska as "elegiac sorrow" and considered to be an excellent "miniature dramatic scene."14 Of course, as the researcher argues, Mickiewicz's work was not a translation of

\footnotetext{
${ }^{10}$ Ibid.
}

11 Ibid.

${ }_{12}$ Antoni Czajkowski, Niektóre poezje (Warsaw: Druk. Banku Polskiego, 1841), 193. Czajkowski published a translation of the entire poem in the following edition of his lyrics. (Antoni Czajkowski, Poezje, Warsaw: W Drukarni Stanisława Strąbskiego, 1845). The revised text will refer to "Italian women and Venetian balls" (Czajkowski, Poezje, 186).

${ }^{13}$ Czajkowski, Niektóre poezje, 196.

${ }^{14}$ Krystyna Poklewska, "Mickiewicz i Mérimée. Z dziejów dwóch wierszy Mickiewicza," in Obrazki romantyczne. Studia o ludziach, tekstach i podróżach (Łódź: Wydawnictwo Uniwersytetu Łódzkiego, 2016), 12. 
the original Serbian folk poetry - which the Polish author was not aware of until 1835 - but a paraphrase of a text prepared by a French writer, Prosper Merimée. In his letter to Sergiusz Sobolewski, Merimée admitted that the volume tilted La Guzla: ou choix de poésies illyriques, recueillies dans la Dalmatie, la Bosnie, la Croatie et l'Herzegovine was simply a product of his imagination, a literary mystification. ${ }^{15}$ In any case, it should be admitted that the poem which was finally written by Mickiewicz is a creative variant of the original, transforming the prose story into a small poetic masterpiece, proclaiming - through the story of a young Slav - a Byronic apotheosis of freedom and manifesting the disagreement with the destruction of human sensitivity.

\footnotetext{
Gdym ostatniego cekina postradał

I gdy mię chytra zdradziła niewiasta,

Chodziłem smutny, a Włoch mi powiadał:

„Dymitry! pójdźmy do morskiego miasta

Piękne dziewczęta znajdziem w jego [murach

I grosza więcej niż kamieni w górach.

Żołnierze w złocie i w jedwabiu chodzą

I dobrze piją i dobrze się bawią:

Nakarmią ciebie, napoją, nagrodzą

I bogatego do domu wyprawią.

Wtenczas twa kurtka srebrnym haftem

[błyśnie,

Na srebrnym sznurku twój kindżał

[zawiśnie ${ }^{16}$.
}

When I finally lost the last sequin And a cunning woman betrayed me, I was in despair, and an Italian told me:

"Dmitry! Let's go to the sea city

We'll find pretty girls within its walls

And more pennies than stones in

[highlands.

Soldiers are clad in gold and silk

And they drink merrily and they frolic:

They'll feed you, give you a drink, reward [you

And they will send you home rich.

Your jacket will shine with silver

[embroidery,

Your poniard will hang on a silver string."

The hope of wealth and a happy life is shattered and the highlander from Dalmatia is left with a sense of a resounding failure, both when it comes to the expected improvement of his fate and relations with people. In exchange for honesty, he is confronted by the mockery of women, hostility of men, and a newly discovered experience of loneliness and alienation. Mickiewicz accumulated an array of pejorative phrases, suggesting betrayal, death and suffering:

Tu czuję w chlebie powszednim truciznę,

(...)

Przykuty zdycham, jak pies na łańcuchu.

(...)

Jestem jak drzewo przesadzone w lecie,

Słońce je spali, a wicher rozmiecie.
I feel the poison in my daily bread here,

(...)

I die chained like a dog on a chain.

(...)

I am like a tree replanted in the summer,

The sun will burn it, the wind will blow [it away.

${ }^{15}$ Ibid., 13.

16 Adam Mickiewicz, "Morlach w Wenecji. Z serbskiego," in Adam Mickiewicz, Poezje, vol. 1 (Petersburg: author's edition, 1829). The quotation comes from: Poezje, vol. 1: Poezje rozmaite 1817-1854 (Lviv: Gubrynowicz i Syn, 1929), 340. 
(...)

Jestem jak mrówka, wychowana w lesie,

Gdy ją na środek stawu wiatr zaniesie. ${ }^{17}$
(...)

I am like an ant, raised in the forest,

When the wind takes it to the middle of

[the pond.

These three short comparisons, which illustrate the state of the subject's feelings, at the same time form components of the "black" legend of Venice: of Venice preying on weakness; gaining momentum thanks to the aroused greed of the inhabitants; and, finally, supported by denunciation and the secretive power of the Council of Ten and the Council of Three. Most importantly, however, of Venice disqualifying the individual. In a study on the history of this island city, popular in the 1850s, such assumptions were mentioned among the unwritten principles of the local authorities: "One cannot rule the state without harming anyone. (...) It is a small thing to harm the individual when the general public benefits from it." ${ }^{18}$ In Mickiewicz's paraphrase of Merimée, officially free La Serenissima paradoxically takes away Dmitry's inner freedom and joy of life, locking him in merchant and military aspirations and well-calculated lusts.

Love as a value against the world that is enslaved, stifled by political and financial goals takes a leading role in the lyrical image of Venice that Zygmunt Krasiński portrayed after his stay there with Joanna Bobrowa in August and September 1835. In the famous barcarolle poem "Do... [incipit: Czy pomnisz jeszcze na dożów kanale]," the poet recalled exceptional encounters with his lover, doomed to failure from the very start, which is suggested by the "mourning" of the gondola, but which gave him a fleeting sense of happiness. The relationship between the subject and his beloved brings to mind the circumstances of a costume ball, during which a love game is in progress, consisting of a clever network of glances, fake gestures or worn masks...

Czy pomnisz jeszcze na dożów kanale

Gondolę moją w weneckiej żałobie?

Czy pomnisz, jakem ja wiosłował tobie,

Patrząc na ciebie, patrzącą na fale?

Pod „Mostem Westchnień” i moje

[westchnienia

Słyszane były. Krew moja płynęła

Blisko krwią ofiar zlanego więzienia,

Lecz jak krew ofiar, w głazy nie

[wsiąknęła;
Do you still recall a gondola of mine in Venetian mourning on the Doge's canal? Do you recall as I was rowing for you, Looking at you, looking at the waves?

Under the "Bridge of Sighs" my sighs Were also heard. My blood was flowing Close to the blood of prison victims, But like their blood, it did not seep into [stones;

${ }^{17}$ Ibid.

${ }^{18}$ The reference is made to the work by Léon Galibert, Histoire de la République de Venise (Paris: Furne, 1855). As cited in: Kazimierz Zalewski, Introduction to Marco Foscarini, dramat w 5 aktach (10 obrazach)," Tygodnik Ilustrowany, no. 59 (1877): 102. Likewise, Zalewski's play is an interesting example of the presence of the Venetian motif in 19th-century drama, ans as such requires separate analysis. 
Wróciła nazad i szałem mi płonie,

W sercu głęboko, na nieszczęście moje,

Bo ty daleka, a ja w innej stronie

I dla nas szczęścia wyczerpnięte zdroje $!^{19}$
It returned and I burn in a frenzy,

Deep down my heart, to my dismay,

For you are afar, and I am away

And springs of bliss for us are no more!

Antoni Edward Odyniec perceived Venice in a similar fashion, referring to it years later as "the city of secrets, intrigues, ambushes and rendezvous, gloomy and indeed delightful." ${ }^{20}$ In the case of the poem by Krasiński, it is interesting to see the use of such a special sign of Venice's political captivity as Ponte dei Sospiri to describe the experience of love. The blood spilled literally by the sullen city rulers and the blood of emotional agitation remain at the same level of intensity and have equal weight. The difference is only in the effects: there can be no doubt that for the subject suffering from love, they are less favourable for they never end. This motif will be analysed later in the article.

Surprisingly, a similar use of Venetian scenery to show emotional drama in the Polish poetry of the time can be found in the youthful collection by Józef Ignacy Kraszewski from 1838, featuring “Paolo. Powieść wenecka" [Paolo. A Venetian Novel], which probably dates back to before $1835 .{ }^{21}$ "Paolo" rises from a purely literary legend of the Italian city since it was not until 1858 that the writer made his first trip to the Adriatic lagoons. Formally and stylistically diversified (including narrative and dialogue parts, gondolier songs, etc.), the text essentially follows the pattern of a poetic novel. Also, the topic seems to be extremely Byronic as it involves a love triangle (or a quadrangle, taking into account the main character's husband, who was merely mentioned on the margin) and a crime of passion. A quiet and calm Venice suspended in the reflection of water, the description of which opens Kraszewski's youthful work, is only seemingly contrasted with the dramatic events of the poem:

Czy widziałeś Wenecją o słońca zachodzie,
Kiedy zorzą wieczorną malowane łodzie
Morze na łonie swoim powoli kołysze,
A śpiewy gondolierów przerywają ciszę?
Czyś widział dwie Wenecje o słońca [zachodzie?
Jedną na wysep tronie i tuż drugą [w wodzie?
Czyś widział wędrowniku, z obcej płynąc [ziemi

Have you ever seen Venice at sunset, When boats, painted with evening twilight, Are slowly rocked on the bosom of the sea, And songs of gondoliers interrupt the [silence?
Have you ever seen two Venices at sunset? One on the island throne, the other one in [the water?
Have you seen, wanderer, sailing from [foreign land

19 Zygmunt Krasiński, Pisma. The Jubilee edition, vol. 6 (Kraków: G. Gebethner i spółka, 1912), 27-28.

${ }^{20}$ Antoni Edward Odyniec, Listy z podróży (Warsaw: PIW, 1961), 403.

${ }^{21}$ Józef Ignacy Kraszewski, Poezje, vol. 1 (Vilnius: S. Blumowicz, 1838), 42-72. Reprint: Józef Ignacy Kraszewski, Poezje, vol. 1 (Warsaw: S. Orgelbrand, 1843), 93-126. All the quotations below come from the Warsaw edition. 
Jak, to wód miasto w pośród morza pływa,

I na niebo się patrząc wierzchołkami [swemi,

Stopy swe w wodzie obmywa? ${ }^{22}$
As the city of waters swims surrounded

[by the sea,

And, looking at the sky with its pinnacles,

Washes its feet in the sea?

The contrast is only apparent as already in this short lyrical picture the suggested duality of the landscape (real and reflected) corresponds to the hidden, tempting power of influence of the inhabitants, especially the inhabitants of Venice. Like Byron in Beppo, Kraszewski continues to ask:

Czy widziałeś wędrowcze, lica

[Wenecjanek?

I czarny włos ich warkoczy,

I czarne ogniste oczy,

I pierś z pod przezroczystych patrzającą

[tkanek?...
Have you seen, wanderer, faces of

[Venetian girls?

And the black hair of their plaits,

And black fiery eyes,

And breasts shining through transparent

[tissues?...

He also immediately warns the reader:

\author{
Lepiej cudów nie widzieć i nie znać boleści. \\ Szczęśliwy, kto nie wiedząc jak świat jest \\ [szeroki, \\ Nie widział tylko jeden, jeden jego kątek, \\ Rodzinne pola mierzył powolnemi kroki, \\ Żył bez wspomnień i żalu - umarł bez \\ [pamiątek. $^{23}$
}
It is better to see no miracles and know [no pain.
He is lucky who misknows how wide the [world is,
He has not seen just one, one corner of it, He measured the family fields with slow
[steps,
Lived with no memories or regret - died
[with no mementos.

The first scenes of the novel are already telling since they portray a beautiful young Italian woman, Paćjenca, and Paolo, who is in love with her, begging God to make their emotional dreams come true. Both prayers are primarily human, i.e. focused on the desires to be satisfied here and now. It is easy to recognise the repetition of Byronic patterns in the psychological and bodily construction of Kraszewski's characters, giving priority to lusts and feelings rather than morality and reason. There are also visible traces of knowledge of frenetic literature in "Paolo," including some similarities to Agaj-han, a novel by Zygmunt Krasiński. ${ }^{24}$ None of Kraszewski's characters embodies the classic good and innocence. Paćjenca - unhappy to be married to a rich but old Venetian patrician - is depicted as a typical woman of the South, temperamental and selfish, who is aware of her own sin and the inevitability of God's punishment for the broken vows, but who is not ready to withdraw from her relationship with young Francesco even for a moment.

${ }^{22}$ Kraszewski, Poezje, 94.

${ }^{23}$ Kraszewski, Poezje.

${ }^{24}$ I have not found any confirmation that Kraszewski was familiar with that work by Krasiński published in Wrocław in 1834 and, in any case, it is more about similar sources of literary inspiration than a literal reference. 
There is both the intransigence that characterises the most famous couple of Dante's Hell and the proverbial Venetian foresight, which, in spite of despair, makes the woman wear a mask in front of other people. Francesco represents, in turn, the type of Italian gigolo who, with good-natured thoughtlessness, continues the affair with Paćjenca, but will not refuse to go out with another rich lady if he expects some benefit for himself. ${ }^{25}$ Of course, the strangest character for the reader is Paolo. His fascination with Paćjenca, despite his childhood age, has nothing to do with the platonic adoration of a lad; there is the cruel desire of a mature man in it.

$\begin{array}{ll}\text { Pożera ją przy świetle wieczora bladawem. } & \text { He devours her in the pale evening light. } \\ \text { Wzrok jego chciwy, białe przelata ramiona, } & \text { His greedy gaze flickers over her white } \\ \text { Piersi jej, kibić - i przy stopach kona. } & \text { [shoulders, } \\ \text { Któż to? - To chłopiec mały - jeszcze w } & \text { Her breasts and waist - only to die at her } \\ \text { [jego łonie } & \text { [feet. } \\ \text { Dziecinne serce spokojnie bić musi. } & \text { Who is it? - He is a little boy - still in his } \\ \text { O! nie! - Patrz, oko jak w tych piersiach } & \text { [chest } \\ \text { [tonie, } & \text { A heart of a child must calmly beat. } \\ \text { Jakie westchnienia w własnej piersi dusi. } & \text { Oh, no! - Look, his eye is sinking in the } \\ \text { O! nie - słońce ten kwiatek rozwinęło } & \text { [breasts, } \\ \text { [wcześnie, } & \text { What sighs he is thwarting in his chest. } \\ \text { Choć młody dumać musiał i kochać choć } & \text { Oh, no! - the sun opened this flower too } \\ \text { [we śnie. } & \text { [soon, } \\ \text { Gdy świat go ślepy dziecięciem nazywa, } & \text { He must have dreamt and loved if only in } \\ \text { On w łonie męskie serce i duszę ukrywa. }{ }^{26} & \text { [dreams. } \\ & \text { When the blind world calls him a little child, } \\ & \text { He is hiding a man's heart and soul in his } \\ & \text { [chest. }\end{array}$

Paolo's imagination goes beyond the principles of biology, he is a child of nihilism, a child with no moral boundaries, a contradiction of innocence. Moreover, envy of Paćjenca's lover and his "withered hopes" make the boy commit a brutal murder which was preceded by a cunning plot.

Płyń trupie z wodą - czekają na ciebie,

Potwory morskie z paszczęki głodnemi.

Płyń, cóż cię jeszcze wiąże do tej ziemi?

Morze w swym łonie chłodnym cię [pogrzebie,

Tam prześpisz sobie, aż do dnia sądnego! ${ }^{27}$
Swim, corpse, with the water - there await [you

Sea monsters with their hungry mouths. Swim, what else binds you to this land? The sea will bury you in its cool bosom, You will sleep there till judgment day!

${ }^{25}$ The relationship of Paćjenca, her lover and her husband evokes associations with the authentic love affair of Byron with the young Contessa Guiccioli, practically by the side of her aging spouse. Cf. Antoni Lange, Lord Byron, jego żywot i dzieła, (Warsaw: M. Arct, 1904), 50-52 [under the pseudonim of Antoni Wrzesień].

${ }^{26}$ Kraszewski, Poezje, 95.

${ }^{27}$ Kraszewski, Poezje, 111. 
"The Venetian trifle" by Kraszewski benefits from the ambivalent construction of the figure of Paolo. His dark, erotic desires, which are not subject to any restraints of the external world, certainly point to the epigonic variant of Gothicism. At the same time, however, the writer retains a certain psychological truth in the portrayal of the character. When Paolo, having killed Francesco, returns to Paćjenca and boasts of his crime, and when, above all, he offers himself to her in place of her murdered beloved, he seems to be extremely naive and infantile rather than demonic. It is clear that he has not grown to understand what love is; his attitude is primarily indicative of his mental and emotional immaturity.

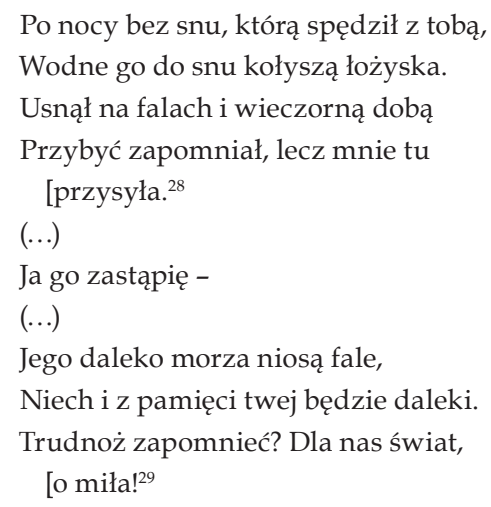

After a sleepless night he spent with you, He is rocked to sleep by water beds. He fell asleep on the waves and forgot To come in the evening, but he sent me [here.

I will replace him -

(...)

He is carried far away by the waves, May he be far from your memory as well. Is he hard to forget? The world is for us, [my dear!

In the end, Paćjenca - struck by the tragedy - throws herself into the waters of the canal, followed by Paolo. The end of this story - also in view of other early works by Kraszewski - is very telling. Gondoliers, sailing near Paćjenca's palace the following morning, find in the water the two corpses of the girl and the boy, stripped of everything, and they brutally push them in the direction of the sea. The last song of the gondolier reinforces the vision of Venice from the first fragment of the poetic novel, and the reader can no longer have any illusions: the idyllic character of the place is only fiction, a mask, a result of human efforts to conceal the dark truth.

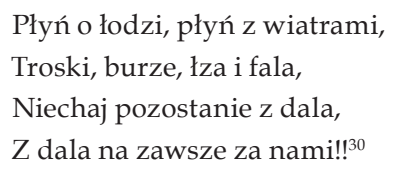

\author{
Sail the boat, sail with the winds, \\ Worries, storms, tears and waves \\ Let them stay away, \\ Forever away behind us!!
}

Did Kraszewski see the risk of enslaving a human being with the sensuality in Venetian culture, especially in the moral freedom linked with it due to Byron? Could he acquire the conviction of Venetian hypocrisy and

\footnotetext{
${ }^{28}$ Kraszewski, Poezje, 117.

${ }^{29}$ Kraszewski, Poezje, 118.

${ }^{30}$ Kraszewski, Poezje, 126
} 
promiscuity from reading Beppo, which is full of irony? One thing is certain: the presented lovers' affections do not move the reader with the fatal force of Romantic attraction, but rather frighten with a kind of amorality and complacency whose causes are mostly social and cultural, with the responsibility falling indirectly on the Venetian upbringing. A good illustration of this is the following description of a Sunday morning:

Dzień był, morze jaśniało, a zewsząd lud [mnogi,

Płynął, szedł, leciał pod kościołów progi.

Brzmiały dzwony niedzielne, panie [i panowie

Tydzień światu służywszy, w dniu jednym [godzinę

Szli spędzić z Bogiem na krótkiej [rozmowie,

I serc światem skalanych, przynieść mu [daninę.

Kto tydzień we krwi ludzkiej broczył, Kto tydzień łzami karmił się cudzemi, Czoło bezwstydne gnąć do samej ziemi, Marmur kościoła, łzą pokuty moczył. I ledwie wyszedł za święcone progi, W dawnego życia puszczał się nałogi;

(...)

Na kanałach, w odkrytych gondolach lud [mnogi,

Płynął pod marmurowe dożów gmachu [progi

Przeszłej mocy Wenetów pomnik okazały.

A z dala cudzoziemskie okręta płynące

Działowym hukiem witały,

Panią morza Wenecją i pana dnia [- słońce! ${ }^{31}$
It was day, the sea was bright, and crowds [of people

Kept swimming, walking, flying to church [doors.

Sunday bells chimed, and women and men,

Having served the world for a week, went [to spend

One hour that day on a short conversation [with God,

Bringing him tribute with hearts fouled [with the world.

Those who imbrued their hands in human [blood,

Those who fed on others' tears in the week, Bent their impudent foreheads down to the [ground,

Moistened the church marble with a tear of [atonement.

And hardly had they left the consecrated [door,

When they fell back into the habits of their [old life;

(...)

On the canals, in open gondolas crowds of [people

Kept swimming to doges' marble palace [doors,

The monument of the former power of the [Veneti.

And foreign vessels sailing from afar

Welcomed with the cannon roar

Venice, sea queen, and the lord of the day [the sun!

Hence, it seems that Kraszewski's youthful text is, on the one hand, inspired by Byron's writing but, on the other, its message is anti-Byronic; it is possible to sense a warning against exotic customs and excessively strong passions, which are not constrained even by religion.

${ }^{31}$ Kraszewski, Poezje, 112-113. 


\section{"Like on a coffin bosom"}

The words of this subtitle are taken from Act III of Maria Stuart by Juliusz Słowacki and, obviously, confirm the influence of Byron's imagination on Polish poets. This passage was quoted by Olga Płaszczewska, pointing to the conventionalised landscape of death, which Romantics built from Venetian details. ${ }^{32}$ Common elements connecting the 'queen of waters' with death include: black gondolas, the night and the moon, lights reflected in the water, singing coming from afar. They are accompanied by a gloomy, melancholy mood. Indeed, all these components can be found in in Słowacki:

And smiled - I hear the song of Tasso echoing,

As - so it seems - I'm borne on the canal

By a gondola festooned with black crepe,

As if in a long coffin... As I pass.

The windows of the palaces shine bright -

Casting columns of light upon the waves,

House after house, my gondola speeds on,

Borne by the current, and above me, high,

Aloft, the golden moon sheds her sad light. ${ }^{33}$

Krasiński also notices death in Venice, but he is far more willing to address this topic in his correspondence or prose rather than in poetry. In addition, he associates the motifs of death with historiosophical diagnoses more often than other artists. The poetic prose written in French titled "W Wenecji" ${ }^{34}$ [In Venice] opens with an idyllic picture of a gondola trip at dusk, with light wind, when the subject can dream among the rays of the setting sun. It turns out, however, that his imagination directs him towards the cruel past, each "wave coming slowly towards the Lido seemed like a bloody shroud that was unfolding (...) only to reveal the bodies and bones of the dismal and terrible people who used to live in these places and nourished tyranny in their hearts with a dagger in their hands and the words of freedom on their lips. Their tyranny had its beautiful moments though, and the chains of oppression shone with the glow of victory." ${ }^{\prime 35}$ In a way typical of him, Krasiński moves from the landscape perceived here and now, confirming the existence of sensual, eternal beauty, to the space

32 Olga Płaszczewska, Wizja Włoch w polskiej i francuskiej literaturze okresu romantyzmu (1800-1850), 239.

${ }^{33}$ Juliusz Słowacki, Maria Stuart, act III, scene VII, in Juliusz Słowacki, Four Plays: Mary Stuart, Kordian, Balladyna, Horsztyński, trans. Charles Kraszewski (London: Glagoslav Publications, 2018), 56. More realistic travelling accounts from Venice of the day show, however, how schematic this image was. Michał Wiszniewski wrote of gondoliers: "[...] they rarely sing, they rather shout the songs of Tasso; their evening singing is wild and unpleasant." Cf. Michał Wiszniewski, Podróż do Włoch, Sycylii i Malty, vol. 1 (Warsaw: S. Orgelbrand, 1848), 194.

${ }^{34}$ Zygmunt Krasiński, "À Venice," in Zygmunt Krasiński, Pisma (Utwory francuskie 18301847), vol. 6 (Lviv: Księgarnia Polska B. Połonieckiego, 1904), 307.

${ }^{35}$ Ibid., 307. 
of supra-individual memory and community experience of history, so as to obsessively aestheticise and revive it. He declares quite in earnest:

Even crimes take great shape when the years passed and the murderer's dagger throws terrible but grand flashes through the darkness of time. The fallen greatness, whatever its supports and foundations were, always remains gripping for posterity; having forgotten about torture and the Bridge of Sighs, I was only thinking of the Bucentaur and the Lion of St Mark. ${ }^{36}$

The intensity of this process of imagination is clearly growing. Until a certain point, scenes of glory of the former Kingdom balance out with visions of its crime, yet gradually they become overshadowed by images of a growing bloody catastrophe which turns the former world of human ambitions and talents into Dante's hell. The poet recalls the palaces and squares of Venice, imagines the places that are delightful and frightening, looks at the Ponte dei Sospiri, and repeats: "there is no hope here. (...) drops of blood were trickling from everywhere and you could hear thousands of sighs, which for so many centuries had not been able to get out of here."37

This youthful catastrophism of Krasiński seems rather total and anarchistic since it does not accept any sense on the path to nothingness that it recognises, no moral consolation or conditional exceptions to the work of destruction: "neither fame and virtue nor crime can stop the extermination for a moment." 38 Therefore, it is necessary, as the daydreaming narrator concludes, to believe that what is left of man's spiritual struggle with the fate, both in the individual and collective dimension, is less powerful than the "physical order of things." Why is this happening, what decides about the death of the spirit of the nation, the moment of the final defeat of the "Queen of the Adriatic?" Finally, the poet - in some desperate gesture - grants Venice the right to a future; he does so not in the name of human achievements, but in the name of the divine element of goodness manifested in nature which can save the degraded humanity:

Venice will be there. I read it in the blue of the sky, which rises above its domes, and in the gentle glow of the stars reflected in its waters. I can hear it in the murmur of the waves, in the gusts of the wind, and I can feel it in the breath of the breeze that brings with it the scent of the flower. ${ }^{39}$

The poetry of the period in question often combines the motif of death with several symbols of Venice's literary existence, ${ }^{40}$ among which an im-

\footnotetext{
${ }^{36}$ Ibid., 308.

${ }^{37}$ Ibid., 311-312.

${ }^{38}$ Ibid., 313.

${ }^{39}$ Ibid., 318-319.

${ }^{40}$ In the introduction to her book titled Wenecja mityczna, Aleksandra Achtelik notes that the cultural stereotype of the city is built around a limited set of metaphors, and all reconstruction attempts are in some way done by making references to them. She refers to them, after Marcin Czerwiński (Marcin Czerwiński, Profile kultury, Warsaw: Wiedza Powszechna,
} 
portant place is occupied by the black gondola. It had already appeared in works by Słowacki and Krasiński, but it was brought to the fore in a poem by Floryan (Stanisław Marek Rzętkowski) titled "Żałobna gondola" [A Funereal Gondola], published in the weekly magazine titled Wędrowiec in 1866. ${ }^{41}$ Despite some stylistic and linguistic clichés, the poem depicts a completely different way of constructing the landscape of death, disparate from that which is typically Romantic, Byronic and strongly metaphorised. It autonomises the space of Venice, frees its image from allusions and historiosophical or national associations, opens up to the impressionality of the description, proposing an existential code of reading. The body of a young and beautiful woman covered with a shroud rests in the eponymous gondola. The silhouette of the deceased girl, taken to the island of San Michele, makes one think of Ophelia from the famous Pre-Raphaelite work by John Everett Millais. Floryan puts emphasis on the movement of the gondola: the reader can easily imagine the sharpened bow of the boat gliding "on a lustrous Venetian wave." The vastness of the lagoon's waters, the wind, the glow of the night sky, splashing drops of water - all of nature that refuses to succumb to death - seems to surround the girl's body on this last journey, to bring her back to life for another moment:

\footnotetext{
Na umarłej poruszona łonie

Szemrze z wiatrem śnieżnej bieli szata,

Nad jej głową z powiewami wzlata

Włos - jak wstęga ponad ciche tonie...

Jej powieki kryją ocz płomienie,

Ust karminy, to milczenie samo...

Ach!... już z nich nie wzleci modłów pienie

I miłosne ścichło już: io t'amo!... ${ }^{2}$
}

The snow white robe murmurs with the wind Moved on the bosom of the deceased, Her hair flies with the gusts over her head, - like a ribbon over quiet depths...

Her eyelids hide the flames of her eyes, The carmine of her lips is silence itself... Alas! no prayers will be uttered by them And no more will they say io t'amo!...

The poet reconstructs the point of view of a mourner not reconciled with the loss, waiting for a miracle and losing hope with every second of this sea journey.

Po lustrzanej mknie gondola fali,

Porze głębię na dwie strony świata...

Pieśń żałoby z łona jej ulata

Coraz ciszej... coraz wyżej... dalej..
The gondola slides on a lustrous wave, Dividing water depths into two parts of [the world...

A song of mourning flies from its bosom Quieter and quieter... higher and higher..

[further... 
A znad brzegu, co się w górę wzbija,

Z niemą groźbą lśniącej wód przestrzeni,

Dzwon wieczorny, wtórząc smętnej pieśni,

Cichym jękiem brzmi: Ave Maria. ${ }^{43}$
And from above the shore, which rises up, With the silent threat of shining water, The evening bell, echoing the doleful song, Quietly moans: Ave Maria.

A maze of streets and canals, which so often surprises Poles in Venice, at first gives way to the open space, allowing the boat to move quickly. ${ }^{4}$ Later, however, the poet describes the gondola as "dividing water depths." The bow wave which is formed creates an impression of drawing a dividing line on the water; it is a very special line since it is not only on the surface. It refers to "two parts of the world," which the reader may interpret as a metaphor for heaven and hell; death and life after death. The seemingly realistic route through the lagoon to the place of burial changes into a spiritual journey towards eternity. The movement towards it is definite, final, inevitable.

While the symbol of the gondola serves to express the individual experience of death, the subject of the death of the city - which was gaining popularity in the Polish literature of the 19th century - is presented somewhat differently. Feliks Wicherski, an author associated with the literary circles of St. Petersburg, wrote a sonnet "Wenecja" [Venice], which was published in the volume of verse titled Poezje [Poems] in 1844. In the first five verses, the poet describes the pleasure of swimming "in the crystal waters of Adriatic." He compares this state to an act of physical love: "The breast of the gondola lovingly touches the water front." ${ }^{45}$ The observed space of the lagoon surrounding the city awakens in the subject an aesthetic joy, an exaltation caused by the moonlight and the beauty of the setting sun, which seems to "light up" the towers and crosses visible from afar. Visual impressions are complemented by sensory sensations: aromas and hot air intermingle to create a charming reality. The first delight, however, is soon undermined by a series of questions posed by Wicherski, who clearly imitates Mickiewicz's diction from the Crimean Sonnets (particularly "Pielgrzym" [The Pilgrim]).

Lecz czemuż ta czarowna milczy okolica?

Gdzie jej szumna, bogata i groźna stolica,

Dająca rozkosz, złoto i rozkazy światu? ${ }^{46}$
But why is this charming place silent?

Where is its noisy, wealthy and fierce capital,

Giving pleasure, gold and orders to the [world?

The reflective parts of Wicherski's sonnet concern the transformation of the powerful city into a "faded aurora," which has lost all the attributes of its former glory and splendour.

${ }^{43}$ Floryan, “Żałobna gondola,” 129.

${ }^{44}$ Maria Konopnicka will set off for Venice much later, in the eighties. In her view, a gondola trip will mean opening to the sea, to an enormous space which is ultimately free.

${ }^{45}$ Feliks Wicherski, Poezje (Petersburg: E.Ostapowicz, 1844). As cited in: Zbiór poetów polskich w wieku XIX, vol. 2, ed. Paweł Hertz (Warsaw: Państwowy Instytut Wydawniczy, 1961), 938.

${ }^{46}$ Zbiór poetów polskich w wieku XIX, 938. 
Tysiąc lat twego życia potargała Parka,

Gdzie twe floty, potęga, i senat, i doża? ${ }^{47}$
A thousand years of your life were ruined

[by Parka,

Where are your fleets, your power, your

[senate, your doge?

The initial impression of the idyll, experienced in the twilight on the lagoon, does not last long. The subject turns to the city again since nature itself seems to be insufficient; as if it was orphaned, devoid of the support of the once "noisy, wealthy and fierce" capital, deprived of power. The silence of the dying, forgotten Venice has only a partially political dimension: what matters, above all, is its cultural and historical aspect.

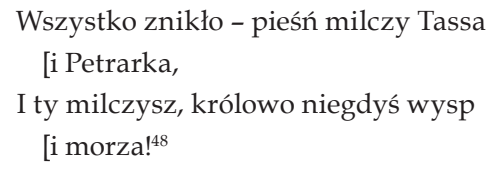
All perished - silent are songs of Tasso [and Petrarch,
And you are silent, once the queen of isles [and the sea!

A different poetic concept was represented by Antoni Czajkowski, a poet loosely associated with the Warsaw bohemia, a participant of meetings in Cech Głupców [the Guild of Fools]. His poem titled “Ostatni ślub Doży, 1797” [The Doge's Last Marriage, 1797] opens with an image of the boisterous, bustling city, filled with the joy of crowds of people who once again came to watch Venice's marriage of the sea (the famous sposalizio del mare), a tradition initiated at the beginning of the 12th century. It is worth reminding that the festival, which takes place on Ascension Sunday every year, combined religious and state elements from the very start. ${ }^{49}$ After Sebastiano Ziani had received the ring from Pope Alexander III, the alliance of the Republic with the element surrounding it was renewed in an exceptionally ceremonial manner. The Doge sailed aboard Il Bucintoro to the sea, at the height of the passageway between the Lido and the town of Litorale del Cavallino, and he threw a golden ring into the water "as a sign of true and eternal reign." 50

The Venice from Czajkowski's work is compared to a majestically decorated ship whose mast is the campanile of St. Mark ("...) and beneath there was music from / sparkling golden purpled waves / With the sun above them $\left.(. .)^{\prime \prime 51}\right)$, thus Bucentaur becomes a ship on a ship. The space gains smoothness, fills with a wealth of shine, color, smell and sound. Venice and its inhabitants create a harmonious, sensual, serene world of people and nature. In addition, Czajkowski exposes the femininity of Venice, which is depicted as the Doge's beloved illuminated by the rays of the sun:

${ }^{47}$ Zbiór poetów polskich w wieku XIX, 938-939.

${ }^{48}$ Zbiór poetów polskich w wieku XIX, 938-939.

${ }^{49}$ It was a reminder of the 1177 truce between Pope Alexander III, Frederick Barbarossa and the Republic of Venice, which ended the conquest of Dalmatia - a proof of recognition of the exceptional rank of Venice on the Adriatic Sea.

${ }^{50}$ Danuta Quirini-Popławska, “Geneza i rozwój 'pływającego miasta-państwa' Wenecji," in Oblicza wody w kulturze, eds. Łukasz Burkiewicz, Paweł Duchliński, Jacek Kucharski (Krakow: Wydawnictwo Akademii Ignatianum, 2014), 66-68.

${ }^{51}$ Antoni Czajkowski, Niektóre poezje (Warsaw: Druk. Banku Polskiego, 1841), 106. 
To znowu jak piękna huryska na

[Wschodzie

Kąpała swe wdzięki wśród morskich

[przezroczy,

I leżąc na wyspach urocza i hoża

Spojrzała lubieżnie $(. . .)^{52}$
And again like the beautiful Houri in the

[East

She bathed herself in transparent sea

[waters,

And lying on the isles - pretty and brisk -

She took a lewd glance (...)

Erotism and music represent the components which link "scattered isles" of the lagoon, and the ceremony acquires the character of an amorous complementation of political agreements and important, precious interests. The strangeness of Doge is conspicuous against the background of this triumphant celebration. The date in the title points to Ludovico Manin, who held the office since $1789 .{ }^{33}$ Admittedly, he externally confirms the splendour of the city (the poem enumerates the ducal insignia which co-creates the majesty of the figure, such as the coat, purple, the Doge's crown), but he remains distanced from the general euphoria of the crowd. It is a completely separate figure. The publisher's note includes information about the protagonist of the poem - in fact, with reference to historical sources - that this is "a walking mummy." Indeed, this is how Czajkowski creates this character. The Doge is "grey-haired," has "stone cheeks," "a pale face," "thin hair," "dimmed, open, goggling eyes," and his trembling body makes him "stagger with the ring."54 "The Doge is dead" - this phrase crowns the fourth stanza of the poem. The whole scene of the Venetian marriage of the sea becomes a parody of nuptials due to the Doge's behaviour. The Doge already knows that the Venetian reality will soon comprise only memories, the glorious memory of past triumphs, without any hope of an autonomous and independent existence for the nation. The main protagonist of "Ostatni ślub Doży" is a tragic and very romantic figure, taking on himself the consciousness of the defeat, but also humanly unable to bear it. The Doge is looking for an escape in the bygone world of his private experiences and feelings. He can control this sphere of life whereas what is happening here and now affects him only seemingly.

$$
\begin{aligned}
& \text { (...) - tak on żywot cały } \\
& \text { Już skończył - zapisał. Dziś ślub - morze } \\
& \text { [- dzwony, }
\end{aligned}
$$

(...)- thus his entire life came to an end

- he wrote it down. Today the nuptials -

[sea - bells,

${ }^{52}$ Czajkowski, Niektóre poezje.

${ }^{53}$ The eponymous "last Doge" took office in 1789. In the face of Napoleon's invasion of Italy, he did not want to shed any blood of the Venetians. First, he attempted to be neutral, then he rejected the ultimatum of general Junot in April 1797, negotiating in secret with the Austrians. When the French took Venice on 25 April, there was no chance of winning. The Doge abdicated on 12 May. The official surrender contract, for which he was reproached by his compatriots, was signed on 16 May. Despite proposals from the French, he no longer wanted to hold any office; he gave back the insignia of power of the Doge, including the famous corno ducale, of which Czajkowski wrote, and moved to Palazzo Dolfin Manin. He died in 1802. Zygmunt Krasiński often thought about him, although probably differently (linking him to the wrong policy of the Venetian aristocracy) when he was preparing Nie-Boska Komedia. Cf. Zygmunt Krasiński, Listy do Delfiny Potockiej, ed. Zbigniew Sudolski (Warsaw: Państwowy Instytut Wydawniczy, 1975), 550.

${ }^{54}$ Czajkowski, Niektóre poezje, 107-108. 
Otrzęsły kurz z księgi, lecz duch jej nie [czyta.

On myślą nie patrzy, nie mówi, nie pyta, Lecz stoi nad morzem wybladły, schylony, Z wzniesioną prawicą, suchymi oczyma, I pierścień trzyma. ${ }^{55}$
Shook dust off the book, but the spirit [reads it no more.

He does not look with the thought, nor [speak, nor ask,

But he stands by the sea, pale and bent, With his right arm raised and dry eyes Holding the ring.

Czajkowski attempts to describe the moment of the inevitable confrontation of the illusions which the Venetians have about their future with the great catastrophe already sensed by the Doge (or known to him from unofficial sources). Venice still persists in the frenetic, almost carnival merriment, whose panache is so spectacular that it appears unrealistic, but it is the beginning of the irreversible end of the Adriatic Republic. The hustle and bustle, laughter, giggles, the beauty of the Venetians, the finest costumes, flags, bouquets of roses, garlands - this abundance, which the poet depicts, covers the approaching emptiness, conceals the unrelenting nothingness. And the historical ring is not even thrown, it falls "from the Doge's hands into the golden foam." ${ }^{\prime 56}$ The world created by human ambitions and desires collides with the judgments of History and the Destiny. The recurrent images of the lion shaking its mane acquire an ironic meaning. "The eternal spirit of Venice" evoked in the last stanza of the poem knows the truth about the fate of the participants of this symbolic marriage, which for centuries "curbed the oceans." 57 Meanwhile, the present is bitter, defined - similarly as in Pan Tadeusz [Master Thaddeus] by Adam Mickiewicz, albeit without his half smile - through the epithet "last": the last marriage, the last triumph, the last Doge. The final line seems to be the most puzzling: "And the last Doge in your Doges' crowd, / That does not understand the marriage." 58 What does this mean? In what sense does he not understand the marriage? It seems, after all, that he is the one who knows how little value is attached to the act of marrying the sea; he is not politically blind and does not believe in the sense of the ritual in the face of the fall of the Republic, which will take place only a month from then, and in the face of its own powerlessness. Or perhaps he is unable to comprehend the ludic determination of his own people, who, seemingly uninformed, sense the misfortune but, in accordance with La Serenissima's tradition, puts on a mask and entertain themselves like there is no tomorrow?

Overall, it is difficult to resist the impression that the fact that Czajkowski reached for an episode from the Venetian history of the late 18th century was directly connected with the evaluation of the partitions (perhaps including the 1830 uprising) and the attitude of the society at that time. Was "Ostatni ślub Doży" supposed to be the poet's voice in the discussion on the unpredictability of the verdicts of history or, on the contrary, on the maturity or political naivety of Poles? The ending of the poem leaves some room for

\footnotetext{
${ }^{55}$ Czajkowski, Niektóre poezje, 109.

${ }^{56}$ Ibid., 110.

${ }^{57}$ Ibid., 111.

${ }^{58}$ Ibid., 112.
} 
interpretation. This does not change the fact that this extended narrative text makes quite successful use of Polish-Venetian parallels, creating a pictorial equivalent to the, in fact, patriotic subject matter. Hence, it belongs to a group of works which are worth devoting a separate sequence of considerations.

\section{Why does Poland become Venice and vice versa?}

Maria Janion used to ask a question Why is revolution a woman? ${ }^{59}$ which was transformed by Dariusz Czaja for the phenomenon of Venice, treating another theory as the point de départ: why is it perceived as a woman in European culture? What conditions this perspective of thinking and what consequences does it entail $?^{60}$ On the basis of reading poems from the 1840 s and 1850s, a set of similar dilemmas should be extended to include the question written in the above mentioned mid-title. It also seems necessary to define the nature of poetic political camouflage devices.

The poem of the "red castellan's son," Edward Dembowski, titled "Śmierć żeglarza pod Wenecją" [A Sailor's Death near Venice] ${ }^{61}$ was published in Przeglad Naukowy in 1843. This hendecasyllable, consisting of three fragments of differing lengths treating some unspecified boat disaster off the Venetian coast, was quickly and warmly welcomed by readers, which its literal content was rather unlikely to justify. It is difficult to consider the poem as particularly original: the national Romantic poetry willingly explored - following Mickiewicz - the theme of sailing as a symbol of wandering through life or a storm in the meaning of the drama of national liberation struggles; Dembowski hardly adds anything new to this. A broken rudder, billows, foamy waves, a fiery thunderstorm and black clouds from the first part are a set of typical components of the metaphorical landscape which was normally created to express either a threat to the national cause or a crisis of faith in its sense. Furthermore, the creation of the collective subject, defining itself within a specific generational and worldview community which begins to doubt the old ideals ("Oppressed - and weak we are swimming in the storm" ${ }^{\prime \prime 2}$ ) belongs to the then repeated clichés of patriotic poetry. Without any doubt, in this case it is possible to talk about the crypto-political content of Dembowski's work.

In the second part of the poem, the mood of discouragement and disablement of spirit changes: melancholy gives way to energy, hope, a call for action and the desire to control temporary weakness. The description turns into an appeal.

\footnotetext{
${ }^{59}$ Maria Janion, “Bogini Wolności (Dlaczego rewolucja jest kobietą?)," in Maria Janion, Kobiety i duch inności (Warsaw: Wydawnictwo Sic!, 1996), 5-49.

${ }^{60}$ Dariusz Czaja, Wenecja jest kobieta. Rzecz o wyobraźni, accessed 28 June, 2020, http:// cyfrowaetnografia.pl/Content/2780/Strony\%20od\%20PSL_XLIX_nr3-4-22_Czaja.pdf.

${ }^{61}$ Edward Dembowski, "Śmierć żeglarza pod Wenecją," Przegląd Naukowy, no. 5 (1843): 169-171. As cited in: Zbiór poetów polskich w wieku XIX, vol. 3, edited by Paweł Hertz, (Warsaw: Państwowy Instytut Wydawniczy, 1962) 67-69. Reprint also in: Pieśni poległych, illustrated, ed. Kazimierz Tułacz-Wiśniewski (Warsaw: Wojskowy Instytut Naukowo-Wydawniczy, 1933), 119-120.

${ }^{62}$ Zbiór poetów polskich w wieku XIX, vol. 3, 67.
} 
Czyż już nie wiemy, jaka moc gondoli, Co i wśród burzy sunie się powoli,

A i bez wiatrów - może rączo płynąć? ${ }^{63}$
Don't we already know the power of the [gondola,

Which moves slowly even amongst storms, And can sail swiftly - even without winds?

However, the third fragment, maintained in the form of a story about the dramatic battle which the sailors fight during a storm at sea, is the most elaborate. When finally the beloved city - the island of art and freedom - could be seen from a distance, the ship sinks, and with it the bulk of the sailors. Only the subject seems to have a chance to be saved.

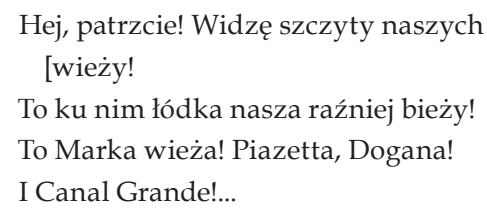

Ha, łódka strzaskana!

Grom w nią uderza! Skała dno wybija.

Na próżno na nas patrzy Wenecyja,

Na próżno całą piękność w morzu dwoi,

Nie ma nadziei - łódź już w wody łonie! ${ }^{64}$
Hey, look! I see the tops of our towers!

That's where our boat's briskly heading!

That's St. Mark's Campanile! Piazzeta,

[Dogana!

And Canal Grande!...

Alas, the boat's shattered!

It's hit by a thunder! A rock smashes the [bottom.

Venice looks at us to no purpose,

It doubles its whole beauty in the sea in [vain,

There's no hope - the boat sinks in the [water!

The number of exclamations and the elliptical syntax reflect the protagonist's extreme tension; they also express violent feelings in the face of a dire peril. At some point, however, a false tone begins to pervade this dramatic account, which is expressively portrayed by Dembowski. The sailor who tries to save his life, losing his strength in the whirls of the lagoon, deliberates whether his death will be in vain or whether it will become a lesson to others. What is this lesson supposed to be like? Certainly full of bitterness:
Bo świat innym dla mnie, niż się zrazu [zdawal,
Bo zmroził me nadzieje! (...)
To straszny przykład i cierpka nauka!
I komuż ją zostawię? Już mnie chłoną [fale. $^{65}$

\author{
Since the world is different for me than it \\ [seemed, \\ Since it has frozen my hopes! (...) \\ This is a terrible example and bitter \\ [knowledge! \\ Who will I leave it to? I am already sucked \\ [by waves.
}

As it can be seen, Venice in se is not to be found, except for a few names which are to identify the place, which would allow to encode the national content and satisfy the censorship. The Venetian theme, unlike in

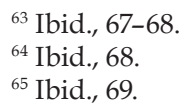


Krasiński or Czajkowski (toutes proportions gardées), was exploited in a purely instrumental way. However, this poem by Dembowski, penetrated by doubt in the sense of patriotic sacrifices, must have arisen surprise among Polish readers and provoked them to take a stand, particularly due to the fact that the author himself was an eternal conspirator, an emissary and a plotter. In this way, Venice became a background for further disputes over the "Polish case."

In 1845 Biblioteka Warszawska printed a fragment of a work by Edmund Chojecki titled "Noc w Wenecji" [A [A Night in Venice], which was published in its entirety a year later, in a separate volume titled Gęśla [A Gusle]. "Noc w Wenecji" is a two-part poem: in the introductory part it takes the shape of a reflexive confession addressed to an anonymous gondolier by another Venetian; the second part is a recollection of the subject's unhappy love for a beautiful but married Roman woman who turns out to have poisoned her stepdaughter. The romance and gothic convention used in the poem only strengthens the protagonist's negative judgment about the world created by human will. From the perspective of this article the most important is the beginning, both due to the Venetian references which are of interest here and its reception. The frame of the story is a gondola trip through the waters of the Canal Grande and the lagoon. The lyrical subject engages in a quasi-conversation with the gondolier and encourages him to boldly abandon the city, where he himself finds only crumbs of the bygone past of the "queen of the seas." What remains from the rich history of the Republic, in which family ambitions played such an important role, are some tangible mementoes in the form of ruins.

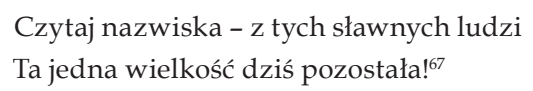

Read the names - what is left today of these famous people is only this grandeur!

This is a field for the "antiquarians" devoid of any vital forces. Unlike Dembowski, Chojecki makes the image of Venice more concrete. He sees that the city demonstrates the old glory here and there, like a retro costume, but in reality, beneath the surface, it is fallen, "infested," experiencing defeat and "the death of the spirit." The vision of humiliated Serenissima brings to mind images of enslaved Warsaw after the insurrection:

Gród, bohatera staje się trumną,

Z której popioły wicher rozmiata.

Snać wielkość wyszła gdzieś na tułactwo,

Ostatki, przemoc w okowach trzyma,

A władcy miasta - to jak robactwo

Zagryzające trupa olbrzyma! ${ }^{16}$
The city of the hero becomes a coffin, From which ashes are swept away by the [wind.

The apparent grandeur turned into exile, Violence is kept at bay, And the city rulers are like vermin Biting the corpse of a giant!

\footnotetext{
${ }^{66}$ Edmund Chojecki, "Noc w Wenecji," in Edmund Chojecki, Gęśla (Lipsk: Księgarnia Zagraniczna, 1846), 1-26. Reprint: Zbiór poetów polskich XIX wieku, vol. 3, 89-91.

${ }^{67}$ Chojecki, Gęśla, 2.

${ }^{68}$ Ibid., 3.
} 
If Chojecki's poem is interpreted using the code of "camouflaged" or "encrypted" reading, both the Venetians and the Poles experience the disintegration of the old world, which seemed glorious and heroic. Their current reality is marked by humiliation and suffering. What are the Venetians left with in this situation? What can Poles do in such vile times? Chojecki's advice sounds rather awkward as the author seems to say: today Venice can only be inhabited by despairing, unhappy people; whoever has a happy soul must flee from here.

Jeśli śmierć ducha wstręt $\mathrm{w}$ tobie nieci,

Wtedy Wenecję mijaj z daleka. ${ }^{69}$
If you abhor the death of the spirit,

Then keep away from Venice.

The inner freedom of the human being could be saved by the beauty of the world, the beauty preserved outside history and politics, signaled here by the fogs, barcarolles and guitar sounds, the nighttime transparent sky, confirmed in art and love; yet Chojecki does not leave many illusions as to the prospects for achieving this in practice. The story of mysterious youthful love, which the subject of the poem reveals to his companion, undermines the sense of dreams, questions the hope of happiness in life.

What was something that Karol Baliński disliked about this vision of Poland-Venice, over which the "angel of perdition flies" ${ }^{\prime \prime 0}$ and that triggered his immediate reply? As the lyrical subject of the poem titled "Odpowiedź Wenecjaninowi" [A Reply to the Venetian] cries:

Ojczyznę moją trupem nazwałeś!

A ja ci mówię: bluźnisz młodzianie!

Nie dziw! salonów okiem patrzałeś! ${ }^{71}$
You called my country a corpse!

And I tell you: you blaspheme, young man!

No wonder! you looked with the elite's eye!

Baliński's accusations were possible precisely because he used the lyricism of the role and the Italian costume, which is clear to his compatriots. The crypto-political code of the poem was substantiated by the biography of the poet, who was the author of the famous poem titled "Farys," a radical activist of post-insurrection patriotic organisations, an exile, repeatedly detained by the tsarist authorities, a vagabond by necessity. "He loved mother Poland above all, he worked for her and greatly suffered for her, he gave her every thought and every effort, all his soul, almost every breath," as Felicja Boberska wrote in 1882. ${ }^{72}$ It may be assumed that Baliński was not really concerned with the attitude of Chojecki himself - a man of the world, an orientalist, someone with a high social position - but his writing required some reaction as it was a voice of a representative of a group, a voice which was increasingly common. "Odpowiedź Wenecjaninowi" is extremely emotional, harsh and full of condemnation for - according to Baliński - one-sided aristocratic judgments and loyalty in relations with the oppressor. As

\footnotetext{
${ }^{69}$ Ibid.

${ }^{70}$ Ibid., 2.

${ }^{71}$ Karol Baliński, "Odpowiedź Wenecjaninowi," in Karol Baliński, Pisma (Poznań: W księgarni Jana Konstantego Żupańskiego, 1849), 57-60. The poem is dated 1845.

${ }^{72}$ Felicja Boberska, Karol Baliński. Lecture (print from Reforma), (Krakow: Reformy, 1882), 5.
} 
the subject of the poem warns, the yoke can be a snaffle of enslavement and manipulation, which is why despair and doubt are so devastating. It works for the benefit of the enemy. Baliński acts from the position of someone who adheres to two basic principles in life: action and faith, and demands that others also put them into practice at all cost. Not adopting a similar attitude meant for him to be "a parody of a human being" ("Do braci lekarzy" [To Fellow Doctors]) or suffer from the disease of "blindness." Following the poetics of the evangelical blessings, the poet strengthened the importance of courage and he belittled fear. The Venice from Baliński's poem is still snoozing, is still gathering strength, but in a moment, it will turn into a "new giant" raised on the moans of the wronged.

\begin{tabular}{|c|c|}
\hline Czyż nie słyszycie jak fala grzmiąca & Can't you hear as a thundering wave \\
\hline O most uderza wygięty łukiem? & Hits the bridge with its curved arch? \\
\hline Jakiś jęk z fali miesza się hukiem... & Moaning from the wave mingles with the \\
\hline Ten jęk... to echo westchnień tysiąca! & {$[$ bang... } \\
\hline & This moaning... it is an echo of a thousand \\
\hline$(\ldots)$ & [sighs! \\
\hline I olbrzym zadrży całym ogromem - & $(\ldots)$ \\
\hline I wieko trumny złamie jak drzazgę! & And the giant will tremble with all his \\
\hline A rozjuszony przeszłym swym sromem & [magnitude - \\
\hline Te szczątki jeszcze zdruzgoce w miazgę! $!^{73}$ & $\begin{array}{l}\text { And will break the lid of the coffin like } \\
\text { [a splinter! }\end{array}$ \\
\hline & And enthralled by his past disgrace \\
\hline & He will shatter these remains into the pulp! \\
\hline
\end{tabular}

The poem is a dynamic expressive vision of the future - the foreseeable future which is dormant in the Venetians-Poles like in a volcano. According to Baliński, this means, however, that it is necessary to reverse the social power system. The elite must give way to a fishing boat. This is where future liberators of Venice meet; this is where the "song of life" is sung. It is not a coincidence that one of the stanzas evokes "the spirit of the Carbonari," being an allusion to the Italian "charcoal makers" attacking the Habsburg diktat practically from the beginning of the 19th century and supporting the worker and peasant rebel as part of the process of Italian unification.

Patrzcie! Sycylia już dzwon gotuje

Wezwać na nieszpór Italii syny!...74
Look! Sicily is getting the bell ready

To call Italiy's sons to vespers!....

${ }^{73}$ Baliński, Pisma, 58.

${ }^{74}$ Baliński, Pisma, 60. It could have been an allusion to Attilio and Emilio Bandiera, two brothers from Venice, who attempted to spark an uprising in the Kingdom of the Two Sicilies, or perhaps a reference to the La Giovine Italia movement aiming at the establishment of united and republican Italy, whose members included Giuseppe Mazzini and Giuseppe Garibaldi. Certainly, similar turmoil already swept through Venice, where there was a short-lived rebellion against the Austrians and the proclamation of the republic by Daniele Manin in 1848. 
These are not the only examples of the "Venetian" code used in the poetry of the period in question. Several years after the poetic disputes of Dembowski, Chojecki and Baliński, a similar "Venetian costume" was used by Mieczysław Gwalbert Pawlikowski in Pamiętnik pieśniarza [A Diary of a Singer]. ${ }^{75}$ The motto of the song was taken from a sonnet written by a fellow author, Kornel Ujejski: "Feel forever, keep silent forever! Oh, insane judgment." 76 The author has used a popular literary device, namely a story within a story: between the pages of Dante's Divine Comedy the narrator finds a poem written in octaves, dating back to the reign of John II Casimir and giving an account of love experiences of an Italian lute player at the court of one of the magnates from Podolia.

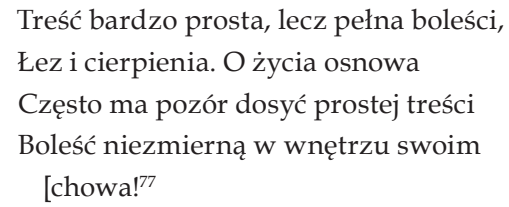

The content is very simple, but full of pain, Tears and suffering. The story of life Often appears to be very simple but It hides immeasurable sorrow inside!

Essentially, the plot is uncomplicated, although its structure may be achronological. A young singer and musician from Venice finds a happy place to live in Poland. He enjoys the recognition of people around him, the growing fame of the artist, the kindness of the host and his daughter. Above all, however, he enjoys staying in a "free" country that respects freedom and values the love of the homeland. The former Poland is presented in the poem as a land close to the traditions of the Hellenic Republic. Even the unrequited love for Jadwiga, the starost's daughter, does not spoil this idyll. Things change after the appearance of a rival, Michał, a poor but uppish nobleman (this thread includes clear references to Pan Tadeusz by Mickiewicz), and an unexpected attack of some Tartars on the starost's house. Michał, who, like the Venetian singer, had no chance of having a relationship with the rich lady, demonstrates energy and bravery in the fight with the enemy, saving the life of the entire family of the magnate. As a reward, he receives permission to marry the starost's daughter, and the Italian is asked to compose and perform a song titled "Engagement amidst Shambles." This dramatic and humiliating experience puts an end to the singer's stay in Poland. He returns to Venice, where, however, he cannot find the expected relief, still analysing his "unhealed scars."78

The way in which the protagonist portrays his beloved is interesting: in his imagination, the golden-haired Pole is reflected against the background of Venetian landscapes:

${ }^{75}$ Firstly, the text was published in Nowiny 1856, no. 8-11 (signed with the initials W. J.), and then it appeared as a separate publication in Lviv in 1856. Reprint of the fragment in Zbiór poetów polskich XIX wieku, ed. Paweł Hertz, vol. 3, 471-473.

${ }^{76}$ Kornel Ujejski, $V$. "Noc zimowa” (from the cycle of sonnets from the period 1839-1840), in Kornel Ujejski, Kwiaty bez woni. Poezje, (Lviv: K. Jabłoński, 1848), 9.

${ }_{77}$ Mieczysław Pawlikowski, Pamiętnik pieśniarza (Lviv: H. W. Kallenbach, 1856), 3.

${ }^{78}$ Pawlikowski, Pamiętnik pieśniarza, 20. 
Edvige moja! w wieczornym lazurze, W promyków nieraz księżycowych

[drganiu,

W morskiego świtu porannej purpurze,

W migocie gwiazdek, w piorunów

[błyskaniu,

W fal zwierciadleniu, w mglejącej się

[chmurze,

[dumaniu

Ja ciebie widzę! $(. . .)^{79}$
Oh, My Edvige! Sometimes in the evening [lazure,

In the rays of the vibrating moon,

In the morning crimson of a sea dawn,

In the twinkling of stars, in the lightning [of flashes,

In the reflection of waves, in a foggy cloud, In half-sleepy shapes, in the afternoon [brooding

I can see you! (...)

It could seem that Pawlikowski's work simply presents a romantic love story, with a recollection of a great emotional catastrophe, which affects the future fate of the protagonist. Nevertheless, this is only the first, the most superficial level of reading. Another level is marked by the initial description of Venice. Although it is still referred to as "the queen of waves," "a lily of the Adriatic Sea" and its son - the Doge - is "the betrothed of the wave," what predominates in everyday existence are "fetters," "enemy violence," enslavement and fratricidal combat. Even though the 17th century reality of Venice was far from being idyllic and there were some abuses of power against political opponents, a similar description in the literal meaning would be simply false. On the contrary, it does work as a metaphorical record of the situation of increasingly tormented and oppressed Poland, which still remembered the drama of 1846 and where patriotic tensions continued to increase as the anti-Polish activities of the invaders were further exacerbated.

Sroższa niewola, kiedy brat ciemięży

Własnego brata, niż gdy wrogów siła

Spoddani w boju połyskiem oręży:

Tam przemoc wroga - ale tu się wpiła

Zdrada Kaima w serce żądłem węży,

I ssie krew serca i pierś twą owiła

Żmii pierścieniem! - O moja ojczyzno!

Wyrwij ją z serca! Niechaj się rozbryzną

Czerepy czaszki pod siłą twej stopy,

Wyrwij ją z serca, choć z serca kawałem!

(..)

Przed światem z trwogi nie zbladło ci lico,

A własnych synów masz być

[niewolnicą?... ${ }^{80}$
Slavery is more severe when a brother [oppresses

His own brother than when enemies galore

Defeat him with shining weapons in a battle:

There the foe's violence but here Cain's [betrayal

Pierced the heart with a serpent sting, And sucks the heart's blood and it twines With a viper ring! - Oh my homeland! Snatch it from your heart! Let skulls Splatter under the force of your foot. Snatch it from the heart, even with the [heart's piece!

(...)

You never grew pale from fear before the [world,

And are you going to be a slave of your [own sons?
${ }^{79}$ Ibid., 19

${ }^{80}$ Ibid., 6. 
The poem makes clear references to the lesson of Słowacki and Ujejski, which additionally confirms this hidden patriotic context of the "Venetian" story. The pictures of the Bridge of Sighs and the nearby prisons full of suffering people also refer to analogous pictures from the Warsaw Citadel, where one of the corridors was dubbed the Bridge of Groans by prisoners. ${ }^{81}$ The city full of spies, denunciation, behind-the-scenes villainy, unjustified accusations, a lack of freedom of speech - this defines Venice and Warsaw to an equal degree. "They oppress us so much, we surrender so much," ${ }^{\prime 82}$ the singer speaks accusingly to his compatriots. In his lament, he also draws attention to the only strength that guarantees human dignity, namely freedom found by the protagonist in the Poland of the 17th century, which should be interpreted as a hidden confession of longing for its absence in the period between the insurrections:

\footnotetext{
Wolności! Szczęścia rodzona Siostrzyco,

Narodów świata promieniu słoneczny,

Kraje gdzie twoje promienie nie świecą,

W duchu podobne Saharze bezrzecznej,

Tyś matką siły, dumy równiennicą,

Dziejów ludzkości tyś kres ostateczny,

Nagrodą świętych w krainie wesela,

Blaskiem, co Boga od ludzi oddziela!... ${ }^{83}$
}

Oh, freedom! The Sister of happiness,
The Sunshine of world nations,
The countries where your rays do not shine,
Are similar in the spirit to riverless Sahara,
You are the mother of strength, a peer of
[pride,
The ultimate end of the history of mankind,
The prize of saints in the land of joy,
The glow that separates God from people!...

Through the "mask" of Venice, Pawlikowski speaks about the situation of the Poland of his time, just before the January Uprising and shortly after the Galician slaughter, and he also juxtaposes it in a nostalgic memory with the idealised - as the country was free - past of the Nobles' Republic. Nevertheless the author, unlike Dembowski or Baliński, does not use a simple Venice-Poland substitute (or possibly Venice-Warsaw), and retains both these spaces as important places for the experience of his protagonist, making it possible to distinguish one more aspect of the work. Indeed the poem - not excluding its foregrounded meanings - also raises questions about the consequences of the cultural confrontation. This was noticed by Cyprian Kamil Norwid, who, on the one hand, accused Pawlikowski's text of being excessively straightforward and "reasonable" but, on the other, appreciated portraying the Venetian as a man of art who does not find the freedom he needs in his own homeland, while in the independent Sarmatian Poland he is faced with a lack of understanding for a song expressing something more than the conventional content. ${ }^{84}$ The struggle between two suitors for the hand of the starost's daughter ends in the victory of the one who is capable of doing, not merely of singing. For Norwid, this was

${ }^{81}$ Cf. Baliński, Pisma, 58.

${ }^{82}$ Pawlikowski, Pamiętnik pieśniarza, 8.

${ }^{83}$ Ibid., 25.

${ }^{84}$ Stanisław Pigoń, “Dwie recenzje literackie C. Norwida," Ruch Literacki, no. 5 (1926): 139-142. 
a confirmation of the difference between Italian and Polish culture. Pawlikowski puts a complaint in the mouth of his protagonist, who keeps singing "though his breasts broke":

W Polsce, gdzie każdy wolny i szczęśliwy,

Gdzie i wieśniacy swobodni w swych [chatach,

W Polsce nie czują poezji prawdziwej;

Li czasem szlachcic już w podeszłych

[latach,

Kleci rytm zimny, twardy, niepieściwy,

W pół w rzymskiej todze, a w pół

[w polskich szatach,

Kiedy śpiewałem, zimno tłum poklaskał,

A śmiał się głośno gdym lutnię

[roztrzaskał!... ${ }^{85}$
In Poland, where everyone is free and

[happy,

Where villagers are free in their huts,

In Poland they do not feel real poetry;

Only sometimes an aged nobleman,

Concocts a cold, hard, untender rhythm.

Half in Roman toga, and half in Polish

[robes,

When I sang, the crowd applauded coldly,

And laughed loudly as I smashed the lute!...

In Pawlikowski's view, being a Venetian is also a diagnosis of the status of a poet or, more broadly, an artist whose destiny is always to be alone. That condition is, indeed, extremely ambivalent, since it does not provide any real consolation.

Tyś mi balsamem, gdy zblednie nadzieja,

Tyś męką wieczną, sępem Promoteja! ${ }^{16}$
You are a balm for me when hope fades,

You eternal torment, the vulture of

[Prometheus!

Three years later, certainly before the Austro-Italian War of 1859, another "Venetian" text was written, namely "Pieśn starego gondoliera" [The Song of an Old Gondolier] by Teofil Nowosielski. ${ }^{87}$ The poem has a very simple and symmetrical construction. The alternate arrangement of eight and seven-syllable lines and regular alternate rhymes allow the poem to reflect the rhythm of the folk song. Similarly, as far as the content is concerned, each stanza consists of antithetical couplets. The first distich always praises Venice's former glory, while the second one explores the phenomena that depict the current degradation of the city.

Niegdyś z lekkiej twej gondoli

Lud twój nucił zwycięstw pieśń,

Dziś, Wenecjo, w twej niedoli

Wieje z ciemnych więzień pleśń.
Once from your light gondola

Your folk hummed the victory song,

Today, Venice, in your distress

Mould blows from pitch dark prisons.

${ }^{85}$ Pawlikowski, Pamiętnik pieśniarza, 34.

${ }^{86}$ Ibid., 9. In this context, if one sees here a hidden question about the status of the poet in "miserable times," then even more emphasis should be placed on the links between Pawlikowski's poem and Ujejski's work, including his poem titled "Syn bólu."

87 Teofil Nowosielski, "Pieśń starego gondoliera," in Teofil Nowosielski, Grzeszki Parnasowe. Garstka poezji lirycznych i humorystycznych (Warsaw: Księgarnia Gebethnera i Wolffa, 1877), 41-42. Reprint in Zbiór poetów polskich XIX wieku, vol. 2, ed. Hertz (Warsaw: PIW, 1961), 656-657. 
O, Wenecjo, w dawne laty

Sławną byłaś z godłem lwa,

Dziś w okowach lew skrzydlaty

Gniewem pała, pomstą drga. ${ }^{88}$
Oh, Venice, you were famous once With the emblem of lion,

Now the winged lion in fetters Seethes with anger and revenge.

In the first two and the last two stanzas the gondolier's confessions are part of the nocturnal, atmospheric, though not very original landscape which description defends itself with the simplicity of the language, some childlike purity or naivety. ${ }^{89}$ In any case, the associations with the eponymous song of the gondolier, which is tender and heart-gripping, are reflected by the image of the moon, which rises above the lagoon as its loyal guardian, at the same time remaining a witness to the historical and political changes bringing lethargy to La Serenissima.

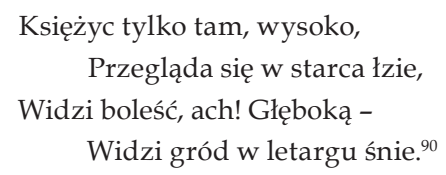

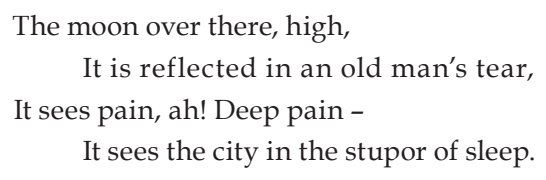

The unpretentiousness of Nowosielski's poem makes it easy to read from a very private, personal perspective, or possibly to situate its message within a universal reflection on the passing away of worldly fame and power. The author's footnote locating the work in the context of the war for the reunification of Italy indicates, however, that it is also necessary to consider an additional, "conspiratorial" code of reading, and that the Venetian staffage is used to express the difficult and painful feelings that the condition of the poet's homeland continues to evoke. It is worth drawing attention to one more aspect of the poem: the old gondolier in the penultimate stanza is called a Venetos rather than a Venetian. This is not a coincidence since hypotheses about the Slavic origin of Venice were popular in the first half of the nineteenth century. They were considered with approval by Adam Mickiewicz, for instance, in the third course of Literatura słowianska [Slavic Literature]. ${ }^{91}$

\section{"These walls are alive": on the pain of longing for Venice}

Finally, considerations about Polish, poetic Venice must also include Album włoskie [Italian Albums] by Teofil Lenartowicz. ${ }^{92}$ It is true that reminiscences connected with Florence, Rome and the South of Italy dominate there, but also the "Queen of the Adriatic" found a modest place for herself. It seems that especially one of the poems deserves to be cited here.

${ }^{88}$ Zbiór poetów, 656.

${ }^{89}$ May this be due to the fact that Nowosielski was used to a young audience, to whom he devoted the majority of his works?

${ }^{90}$ Zbiór poetów, 657.

${ }^{91}$ Cf. Mikołaj Sokołowski, “Wenecja”, in Atlas Polskiego Romantyzmu, NPLP IBL, accessed July 1, 2020, http://nplp.pl/artykul/wenecja/.

${ }^{92}$ Teofil Lenartowicz, Album włoskie (Lviv: F.H. Richter, 1870). 
"Dwaj niewidomi" [Two Blind People] is a poem whose plot is set in Florence. The lyrical situation is constructed in such a way as to highlight the contrast between the material beauty and richness of the Christian tradition, symbolically concretised in the Cathedral of Santa Maria del Fiore, and the "poor people," whom the reader watches together with the poet in the church arcades. One of the blind is a boy, "sightless from birth, poor thing." ${ }^{\prime \prime 3} \mathrm{He}$ represents unconscious beauty ("two pretty eyes came out from underneath his forehead"94), treated by others with undeserved disrespect. The other blind person is an old man, a vagrant, an expatriate who, after all, remembers the sights of his youth and therefore probably suffers more than the boy from a longing for Venice, his "little homeland."
Może mu piękna Wenecja $\mathrm{w}$ oku,
Maybe there is beautiful Venice in his eye,
Może mu w oczach lotne gondole. ${ }^{95}$
Maybe there are swift gondolas in his eyes.

With his characteristic affection towards simple people, Lenartowicz allows the painful images of the lost world to resound in the confession of the blind man. In his very painterly vision, the old man slightly resembles Rembrandt from his extraordinary, late self-portrait. Physically run-down, he livens up with the emotions that fill him. Recalled in the eyes of the imagination of the blind man cuddled to the marbles of the Florentine cathedral, Venice is no longer the crypto-political code that has been mentioned several times here, but it certainly provides a pretext for naming the feelings of the expatriate. Dreams of the blind man, which stem from a deep longing for the landscape close to his heart, are reminiscent of the experience of a character who will appear in Polish literature a decade later, namely Józef Skawiński reading Pan Tadeusz in the lighthouse in Aspinwall.

Gdybyż to ujrzeć Marka kolumnę,

Raz tylko jeszcze przepłynąć Lido,

Potem niech dzwonią, niech po mnie [przyjdą,

Niech nad mym czołem zabiją trumnę.

Tylko niech ujrzę na wód topieli

Płótno okrętu, co się tam bieli,

Tylko pieśń ludu niech mnie otoczy,

A łódź po morza przeleci niebie;

Wenecjo moja! Oddaj mnie oczy,

Ja tu nie widzę nic oprócz ciebie;

Oczami duszy widzę Cię jasno,

Te jedne widzą, te drugie gasną. ${ }^{96}$
If only I could see St. Mark's Column,

Sail back to the Lido this one more time,

Later let them call, let them come for me,

Let them nail the coffin over my brow.

Let me see in the abyss of water

The canvas of the ship, which is there white,

Let the song of the people surround me,

And let the boat fly over the sea's sky;

Oh, my Venice! Return my eyes to me,

I do not see anything here but you;

I see you clearly with the eyes of my soul,

These eyes can see, those are fading away.

\footnotetext{
${ }^{93}$ Lenartowicz, Album włoskie, 94.

${ }^{94}$ Ibid., 95.

${ }^{95}$ Ibid.

${ }^{96}$ Ibid., 96.
} 
It should be noted that these Polish-Venetian fantasies from the poem "Dwaj niewidomi" accurately reflect the most distinctive details of the city on the island (both material and immaterial), as well as describe with great accuracy the state of helplessness or emotional apathy of many simple Polish emigrants forced to endure misery and utter desolation in a foreign country. Undoubtedly, this is due to the aesthetic and ethical sensitivity, which gained Lenartowicz many readers.

\section{"The land of zephyrs" or "a wounded snake"?}

Finally, reference will be made to three short texts showing different yet complementary visions of Venice which inspired the poetry of the subsequent decades of the nineteenth century. The first of them is a rather short song written by Juliusz Strutyński, an ambiguous figure of Polish literature since, despite his Polish roots, he was strongly associated with the tsarist authorities. ${ }^{97}$ He was on a secret mission in Venice as an officer for special operations under governor-general Bobikov in the early 1840s. ${ }^{98}$ One effect of that stay was the four-stanza barcarolle titled "O! cara e bella! W cześć Sylwii" [O! cara e bella! In Sylwia's honour], printed in 1846 by Romuald Podbereski in Petersburg-based Rocznik Literacki. The poem became so popular that Wiktor Każyński decided to compose music for it. There is a refrain in this simple, regular poem composed of six-syllable lines, imitating the $6 / 8$ rhythm, composed of four elements developing in different variants on the same topic, namely the trip of a gondola on the lagoon at night:

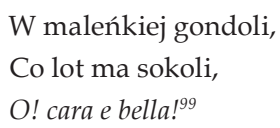

\author{
In a small gondola, \\ Which flies like a falcon \\ O! cara e bella
}

The poem is cheerful in mood and devoid of any political or historical allusions. It emphasises the connection with the surrounding nature typical of Venice. Its aim is to express a sense of paradisiacal jauntiness which unites the travellers in love, amorous detachment from everyday matters, on the way to "the land of zephyrs."

\author{
Na modrej przestrzeni \\ Wysp wieniec bogaty \\ Srebrnymi lśni kwiaty,
}

In the deep blue space

A rich wreath of islands

Shines with silver flowers,

${ }^{97} \mathrm{He}$ was even distinguished for struggling in the war of 1830 . He was loosely associated with the Petersburg coterie, including Michał Grabowski, he also sometimes collaborated with Aleksander Przeździecki. He took part in several uncompleted projects of launching periodicals, such as Przeglądnik Literatury Rosyjskiej i Polskiej or Słowianin. Cf. Andrzej Biernacki, Henryk Głebocki, Strutyński Juliusz, Polski Słownik Biograficzny, vol. 44; accessed June 28, 2020, https://www.ipsb.nina.gov.pl/a/biografia/juliusz-ksawery-lukasz-strutynski\#disqus.

${ }^{98}$ Juliusz Strutyński, Poezje Berlicza Sasa i wspomnienia jego, posthumous edition (Krakow: A. Strutyńska, 1878), 9-10 (here the poem is dated for 1842 and information about the musical composition). Reprint in Zbiór poetów polskich XIX wieku, vol. 2, ed. Paweł Hertz, 512-513.

${ }^{99}$ Zbiór poetów polskich XIX wieku, vol. 2, 512. 
Laurem się zieleni.

Przy blasku tła fali,

Rubinów, opali

Płyńmy tam w gondoli,

Co ma lot sokoli

$(\ldots)^{100}$
Turns green with a laurel.

Against the glow of waves,

Of rubies and opals

Let's go there by gondola,

Which flies like a falcon

(...)

A certain similarity can be found in the mood of a Venetian folk song (Coi pensieri malinconici), ${ }^{101}$ which was paraphrased by Aleksander Michaux and published in Kłosy in 1869.102 Miron shortened the Italian prototype, slightly modifying its rhythm but preserving the climate. A simple appeal to a young girl to abandon her worries and succumb to the joy of seeing the sea and her beloved corresponds to the optimistic image of the people of the South, capable of forgetting themselves and yielding to temporary happiness.

\footnotetext{
W mieście ciemnym, marmurowym,

Sercu smutno wciąż,

Więc po morzu szmaragdowym

Z pieśnią szczęścia dąż!
}

Już z błękitu, złote oczy

Cherubinów ślą,

Swoich spojrzeń blask uroczy

Na twarzyczkę twą! ${ }^{103}$
In the dark, marble city,

The heart is still sad,

Thus sail on the emerald sea

With a song of happiness!

From the blue, Cherubs'

Golden eyes are sending

Their charming gaze

On your face!

The last poem selected for the purposes of this article is also atmospheric. Its author, Wiktor Gomulicki, was connected with the subject matter discussed above due to his later poetry created after his participation in the literary congress in 1888, namely Obrazki weneckie ${ }^{104}$ [Venetian Pictures] and the series titled Z pieśni weneckich [From Venetian Songs], ${ }^{105}$ but already in the sixties he dedicated a poem titled "Z krainy dźwięków (Fragment)" [From the Land of Sounds] to the extraordinary city on the island:

... Rwący jak nurt potoku, jak morze

[zdradziecki,

Syn ciemności, a w szaty strojny

[promieniste,
... Rapid like a stream, treacherous like a sea,

The son of darkness, clad in beaming attire,

${ }^{100}$ Zbiór poetów, 513.

${ }^{101}$ In his travel account, Wiszniewski quoted the seven-stanza version of the song after George Sand (Michał Wiszniewski, Podróż do Włoch..., 94-95).

${ }^{102}$ Miron [Aleksander Michaux], “Pieśni ludowe weneckie I.-II.,” Kłosy, no. 222 (1869): 194; Kłosy, no. 223 (1869): 210. Other poems on Venice by Miron were published in the volume titled Poezje from 1884.

${ }^{103}$ Miron [Aleksander Michaux], “Pieśni ludowe weneckie I.,” 194.

${ }_{104}$ Wiktor Gomulicki, Obrazki weneckie (Warsaw: Druk. Artystyczna Saturnina Sikorskiego, 1896).

${ }^{105}$ Wiktor Gomulicki, Nowe pieśni (Petersburg: Wydawnictwo księgarni K. Grendyszyńskiego, 1896). 
Tam, kędy laury kwitną i niebo lśni czyste,

Niby wąż się rozwija... karnawał

[wenecki. $^{106}$
Where laurels bloom and the sky shines [clear,

It slithers like a snake... the Venetian

[carnival.

This text is disconcerting. It brings strong evaluative descriptions of the city's space, suggesting that it is ruled by dark forces. The impression of the danger is reinforced by the irregularity of the Polish alexandrine with which the text opens. In addition, the poet often uses ellipsis and pauses; the rhythm seems crippled and obscure at times. In addition, Gomulicki refers to various sensual impressions and emotions. He uses a whole palette of colours, scents, sounds, lights, flashes that seem to overlap, creating a dynamic, fluid, flickering, synesthetic description of the Venetian carnival.
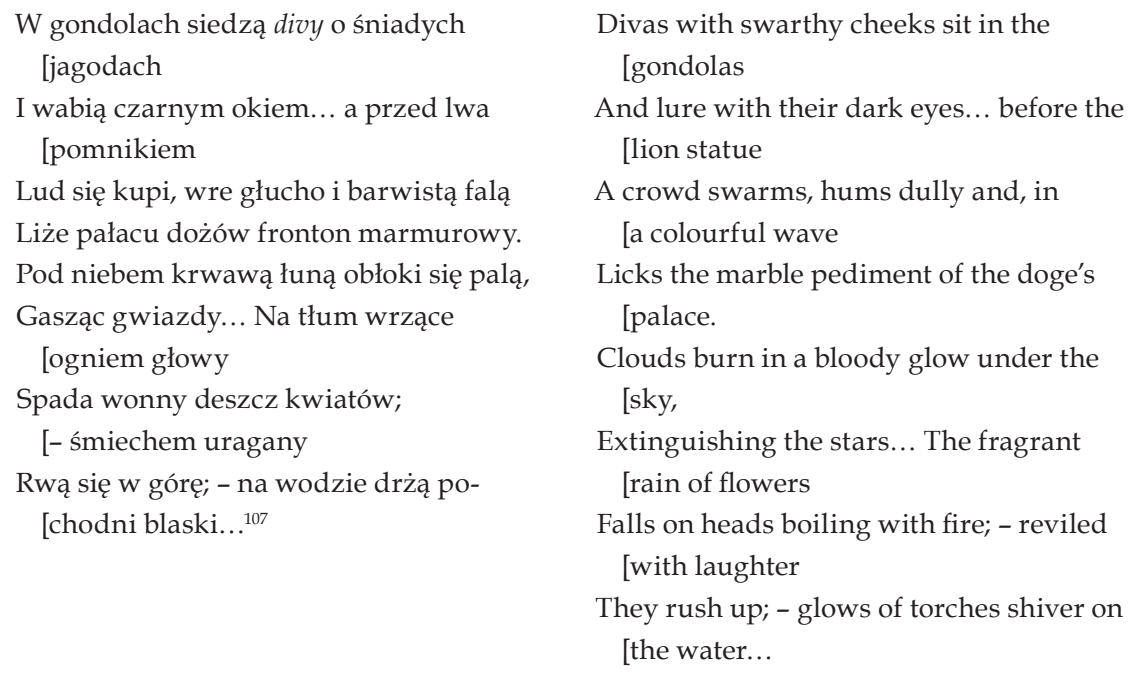

The impressionistic vision of Venice undoubtedly foreshadows Parnassian and symbolic tendencies in Gomulicki's further poetic work. ${ }^{108}$ It seems, however, that it is not only aesthetic impressions that the poet seeks. His vision is not devoid of moral judgment. What is particularly surprising is the image of Venetian crowds: frenzied, bustling, not controlling their euphoria ("Shouts escape from the crowd, like from a hive / And they turn into a roaring thunder..."109). Some of the phrases used by Gomulicki are ambiguous. Since the crowd "hums dully," and at the same time "licks" the pediment of the palace, its intentions are not clear. The carnival is reminiscent of the revolution, underlying conspiracy, an intrigue which is about to break out of the "red city" which he wrote about later in the 1890s. Does it contain any camouflaged fear of the untamed

106 Wiktor Gomulicki, “Z krainy dźwięków (Fragment)," Tygodnik Ilustrowany, no. 46 (1868): 231.

${ }^{107}$ Ibid., 231.

${ }^{108}$ Wiktor Gomulicki, Nowe pieśni.

${ }^{109}$ Wiktor Gomulicki, "Z krainy dźwięków (Fragment).” 
power of the anonymous mob (such an interpretation could partly justify the motto from the novel titled Maria by Malczewski)?

At some point, the form of the poem changes - and together with the shift from the Polish alexandrine to simple regular layout of four-line stanzas $(7,7,7,7,3)$ - the beguiling and poisonous images of Dionysian ecstasy and "half-naked debauchery" come to the forefront. The madness of the carnival is expressed by the song in which there is both pathos represented by the figure of an ascending eagle and wickedness in the form a creeping snake. The dynamic vision ends abruptly, as if the poet was trying to warn that what so engages the masses, excites them and drives them crazy can be as risky as snake venom or lead to sinking "into a dark abyss of the worlds." It is difficult to say what dominates in Gomulicki's poem: the fascination of an observer of an extraordinary show or the fear of a moralist terrified of crossing borders and empowering human egoism. However, it should certainly be noted that Gomulicki's work introduces an important change in the poetic representation of Venice. It is no longer a cipher, a costume for the national cause, protecting against the possessive censorship, no longer the Byronic Southern passion deeply rooted in literature, no longer the past - but it is Venice here and now, its social and political present, that turned out to be sufficiently universal and interesting for the Polish artist.

I do not think that a satisfactory and convincing summary can be made here. This article was given - intentionally and consciously - the form of a specific catalogue complementing the image of Venice in Polish culture. It so happens that the attention of 19th-century researchers was focused mainly on prose, essay and reportage. The drama whose subject matter would concentrate on Venice was explored very rarely, or hardly at all. As far as poetry is concerned, the subject of analysis was more often from the turn of the 19th and 20th century than the first half of the century. It is true that the poems of Maria Konopnicka or Antoni Lange are artistically more interesting than those presented in this sketch. However, in order to see the occurrence of a motif in culture, it is necessary to build, in the first place, an image of the whole.

\section{REFERENCES}

Achtelik, Aleksandra. Wenecja mityczna w literaturze polskiej XIX i XX wieku. Katowice: Gnome, 2002.

Ackroyd, Peter. Wenecja. Biografia. Poznań: Zysk i S-ka, 2015.

Baliński, Karol. “Odpowiedź Wenecjaninowi.” In Baliński, Karol. Pisma. Poznań: W księgarni Jana Konstantego Żupańskiego, 1849, 57-60.

Biernacki, Andrzej. Głębocki, Henryk. Strutyński Juliusz, Polski Słownik Biograficzny, vol. 44. Accessed July 1, 2020. https://www.ipsb.nina.gov. pl/a/biografia/juliusz-ksawery-lukasz-strutynski\#disqus 
Biliński, Bronisław. "Viaggiatori polacchi a Venezia nei secoli XVII-XIX. Venezia e la Polonia nei secoli XVII-XIX." In Venezia e la Polonia nei secoli XVII-XIX. Edited by Luigi Cini. Venice-Rome: Istituto per la collaborazione culturale, 1965, 341-417.

Boberska, Felicja. Karol Baliński. Odczyt (print from Reforma). Krakow: Reformy, 1882.

Brahmer, Mieczysław. Powinowactwa polsko-włoskie. Warsaw: PWN, 1980.

Byron, George. Childe Harold's Pilgrimage, Canto IV. Accessed October 8, 2020, https://www.gutenberg.org/files/5131/5131-h/5131-h. htm\#link2H_4_0006

Chojecki, Edmund. "Noc w Wenecji." In Chojecki, Edmund. Geśla. Lipsk: Księgarnia Zagraniczna, 1846, 1-26.

Czaja, Dariusz. Wenecja jest kobieta. Rzecz o wyobraźni. Accessed June 28, 2020, http://cyfrowaetnografia.pl/Content/2780/Strony\%20od\%20PSL_ XLIX_nr3-4-22_Czaja.pdf.

Czajkowski, Antoni. Niektóre poezje. Warsaw: Druk. Banku Polskiego, 1841.

Czajkowski, Antoni. Poezje. Warsaw: W Drukarni Stanisława Strąbskiego, 1845.

Dembowski, Edward. "Śmierć żeglarza pod Wenecją." Przegląd Naukowy, no. 5 (1843): 169-171.

Dokurno, Zygmunt. "O mickiewiczowskich przekładach z Byrona." Pamiętnik Literacki, no. 47 (1956): 317-348.

Floryan [Rzętkowski, Stanisław Marek]. "Żałobna gondola." Wędrowiec, no. 165 (1866): 129.

Gomulicki, Wiktor. “Z krainy dźwięków (Fragment).” Tygodnik Ilustrowany, no. 46 (1868): 231.

Kaczyński, Grzegorz J. "Geneza i obraz polskiej emigracji we Włoszech.” In Polacy we Wtoszech. Historia, wspótczesność, zmiany. Edited by Karolina Golemo, Bartosz Kaczorowski, Małgorzata Stefanowicz. Krakow: Ośrodek Myśli Politycznej, 2014, 41-70. Accessed November 28, 2020. www.academia.edu/14897219/Polacy_we_Włoszech_Historia_współczesność_zmiany_Poles_in_Italy_History_Contemporaneity_Changes_

Kot, Stanisław. Venezia vista dai Polacchi nel corso dei secoli. Venezia: Montuoro, 1947.

Kozińska-Donderi, Diana. I viaggi dei Polacchi in Italia attraverso i secoli. Moncalieri: Cirvi, 2006.

Krajewska, Wanda. "Polskie przekłady powieści poetyckich Byrona w okresie romantyzmu." Pamiętnik Literacki, no. 71/1 (1980): 153-174.

Krasiński, Zygmunt. "À Venice" / "W Wenecyi." In Krasiński, Zygmunt. Pisma (Utwory francuskie 1830-1847), vol. 6. Lviv: Księgarnia Polska B. Połonieckiego, 1904.

Krasiński, Zygmunt. "Do... [incipit: Czy pomnisz jeszcze na dożów kanale]." In Krasiński, Zygmunt. Pisma. Jubilee edition, vol. 6. Krakow: G. Gebethner i Wolff, 1912.

Krasiński, Zygmunt. Listy do Delfiny Potockiej. Edited by Zbigniew Sudolski. Warsaw: Państwowy Instytut Wydawniczy, 1975. 
Kraszewski, Józef Ignacy. “Paolo.” In Kraszewski, Józef Ignacy. Poezje, vol. 1. Warsaw: S. Orgelbrand, 1843, 93-126.

La porta d'Italia. Diari e viaggiatori polacchi in Friuli-Venezia Giulia dal XVI al. XIX secolo. Edited by Lucia Burello e Andrzej Litwornia. Udine: Forum Edizioni, 2000.

Lenartowicz, Teofil. "Dwaj niewidomi." In Lenartowicz, Teofil. Album włoskie. Lviv: F.H. Richter, 1870, 94-96.

Mickiewicz, Adam. Poezje, vol. 1: Poezje rozmaite 1817-1854. Lviv: Gubrynowicz i Syn, 1929.

Miron. [Aleksander Michaux]. "Pieśni ludowe weneckie." Kłosy, no. 222 (1869): 194; Kłosy, no. 223 (1869): 210.

Norwich, John Julius. Historia Wenecji. Warsaw: W.A.B. 2015.

Nowosielski, Teofil. "Pieśń starego gondoliera." In Nowosielski, Teofil. Grzeszki Parnasowe. Garstka poezji lirycznych i humorystycznych. Warsaw: Księgarnia Gebethnera i Wolffa, 1877, 41-42.

Odyniec, Antoni Edward. Listy z podróży. Warsaw: PIW, 1961.

Pachoński, Jan. "Emigracja polska w Wenecji w latach 1794-1797. Wenecja i jej znaczenie dla emigracji polskiej." Kwartalnik Historyczny, no. 4 (1968): 869-893.

Pawlikowski, Mieczysław. Pamiętnik pieśniarza. Lviv: H. W. Kallenbach, 1856.

Pieśni poległych, illustrated. Edited by K. Tułacz-Wiśniewski. Warsaw: Wojskowy Instytut Naukowo-Wydawniczy, 1933, 119-120.

Pigoń, Stanisław. “Dwie recenzje literackie C. Norwida." Ruch Literacki, no. 5 (1926): 139-142.

Płaszczewska, Olga. Wizja Włoch w polskiej i francuskiej literaturze okresu romantyzmu (1800-1850). Krakow: Universitas, 2003.

Poklewska, Krystyna. “Mickiewicz i Mérimée. Z dziejów dwóch wierszy Mickiewicza." In Poklewska, Krystyna. Obrazki romantyczne. Studia o ludziach, tekstach i podróżach. Łódź: Wydawnictwo Uniwersytetu Łódzkiego, 2016, 11-18.

Pomian, Krzysztof. Wenecja w kulturze europejskiej. Lublin: Wydawnictwo Uniwersytet Marii Curie-Skłodowskiej, 2000.

Quirini-Popławska, Danuta. “Geneza i rozwój 'pływającego miasta-państwa' Wenecji." In Oblicza wody w kulturze. Edited by Łukasz Burkiewicz, Piotr Duchliński, Jarosław Kucharski. Krakow: Wydawnictwo Akademii Ignatianum, 2014, 49-71.

Quirini-Popławska, Danuta. Mit czy rzeczywistość późnośredniowiecznej Wenecji?: urbs populosissima, opulentissima, liberalissima. Krakow: Wydawnictwo Uniwersytetu Jagiellońskiego, 1997.

Słowacki, Juliusz. Maria Stuart, act III, scene VII. In Juliusz Słowacki, Four Plays: Mary Stuart, Kordian, Balladyna, Horsztyński. Translated by Charles Kraszewski. London: Glagoslav Publications, 2018, 29-115.

Sokołowski, Mikołaj. Wenecja. Atlas Polskiego Romantyzmu, NPLP IBL. Accessed July, 1, 2020. http://nplp.pl/artykul/wenecja/.

Strutyński, Juliusz. “O! cara e bella!". In Strutyński, Juliusz. Poezje Berlicza Sasa $i$ wspomnienia jego, posthumous edition. Krakow: A. Strutyńska, 1878, 9-10. 
Ujejski, Kornel. Kwiaty bez woni. Poezje. Lviv: K. Jabłoński, 1848.

Węgrzyn, Iwona. W świecie powieści Henryka Rzewuskiego. Krakow: Wydawnictwo Uniwersytetu Jagiellońskiego, 2012.

Wicherski, Feliks. Poezje. Petersburg: E. Ostapowicz, 1844.

Wiszniewski, Michał. Podróż do Włoch, Sycylii i Malty. Warsaw: S. Orgelbrand, 1982.

Wrzesien, Antoni. [Lange Antoni], Lord Byron, jego żywot i dzieła. Warsaw: M. Arct, 1904.

Zalewski, Kazimierz. "Introduction to Marco Foscarini, dramat w 5 aktach (10 obrazach)." Tygodnik Ilustrowany, no. 59 (1877): 102.

Zbiór poetów polskich XIX wieku, vol. 2. Edited by Paweł Hertz. Warsaw: Państwowy Instytut Wydawniczy, 1961.

Zbiór poetów polskich XIX wieku, vol. 3. Edited by Paweł Hertz. Warsaw: Państwowy Instytut Wydawniczy, 1961.

Maria Berkan-Jabłońska - Ph.D., Professor of the University of Lodz, the Department of Literature and Traditions of Romanticism. Her research focuses on 19th-century literature, especially the tradition of female writing, Polish Biedermeier, Romantic biography, and the widely-understood popular literature of the 19th century (e.g. detective stories). She is the author of: Wizje sztuki w twórczości Zbigniewa Herberta (Łódź 2008), Arystokratka $i$ biedermeier. Rzecz o Gabrieli z Günterów Puzyninie (1815-1869) (Łódź 2015), Weredyczki, sawantki, marzycielki, damy... W kregu kobiecego romantyzmu. Studia $i$ szkice z kultury literackiej kobiet okresu międzypowstaniowego (Łódź 2019); she was the co-editor of Mickiewicz wielu pokolen twórców, badaczy i czytelników (Łódź 2008), Przygody romantycznego "ja". Idee - strategie twórcze - rezonanse (Poznań 2012), "Nie-do-czytane. Polski dramat romantyczny," Acta Universitatis Lodziensis. Folia Litteraria Polonica, no. 1(27) 2015, "Kryminał w XIX wieku, XIX wiek w kryminale," Acta Universitatis Lodziensis. Folia Litteraria Polonica, no. 4(50) 2018.

E-mail: maria.berkan@uni.lodz.pl 